\title{
ISLAM, PATRON SOSIAL, PSEUDO IDENTITAS MASYARAKAT PERKOTAAN DI KOTA MEDAN
}

\author{
Muhammad Habibi Siregar \\ Fakultas Dakwah dan Ilmu Komunikasi UIN Sumatera Utara \\ J1. Willem Iskandar Pasar V Medan Estate, Sumatera Utara, 20371 \\ e-mail: m.habibi.siregar@uinsu.ac.id
}

\begin{abstract}
Abstrak: Kota Medan memiliki masyarakat yang relatif heterogen sehingga sangat diperlukan kesadaran yang tinggi untuk menjaga kondusivitas wilayah ini. Pluralitas bisa dianggap sebagai potensi bukan ancaman terhadap disintegrasi bangsa. Ada dua opsi yang ditawarkan dalam kegiatan yang berkaitan dengan pemberdayaan masyarakat yaitu dengan melakukan melting pot dan non-melting pot. Keduanya memiliki keunggulan maupun kelemahannya masing-masing. Pola pertama biasanya diterapkan pada kelompok masyarakat yang memiliki latar belakang yang sangat berbeda sehingga dibutuhkan satu bentuk identitas baru yang mengikat semua elemen masyarakat yang ada di dalamnya. Sistem ini dilatar belakangi oleh semangat menumbuhkan nasionalisme baru karena warganya berasal dari berbagai bangsa. Pola kedua lebih bersikap akomodatif terhadap nilai-nilai primordialisme warganya. Sistem ini berusaha menciptakan masyarakat memberi kebebasan kepada warganya untuk tetap mempertahankan identitas asal warganya selama tidak mengganggu kepentingan nasional secara umum.
\end{abstract}

\begin{abstract}
Islam, Social Patron, Pseudo Identity of Urban People in Medan City. Medan city has a relatively heterogeneous society so it is highly commended to maintain the condition of this region. Plurality can be regarded as a potential not a threat to the disintegration of the nation. There are two options offered in activities related to community empowerment namely; by doing the melting pot and nonmelting pot both have their own advantages and disadvantages. The first pattern is usually applied to groups of people who have very different backgrounds so that it takes a new form of identity that binds all elements of society in it. This system is based on the spirit of growing new nasioanalisme because citizens come from various nations. The second pattern is more accommodative to the values of its citizens primordialism. This system seeks to create a society giving freedom to its citizens to retain the identity of their citizens as long as it does not interfere with the national interest in general.
\end{abstract}

Kata Kunci: etnisitas, Islam, melting pot, patron sosial, social identity 


\section{Pendahuluan}

Medan merupakan ibukota Propinsi Sumatera Utara yang merupakan salah satu kota paling besar di luar Pulau Jawa yang memainkan peran cukup penting dalam berbagai bidang kehidupan masyarakat. Medan bukan hanya sebagai kota pemerintahan, tetapi juga sebagai kota perdagangan yang menjadi tempat lokasi perwakilan perusahaan multi nasional di daerah ini terutama di bidang perkebunan. Medan memiliki daya tarik tersendiri bagi banyak orang untuk datang dan tinggal karena terletak di lokasi yang sangat strategis. Letak geografisnya yang sangat dekat dengan Selat Malaka sebagai jalur perdagangan paling padat di dunia menjadikan kota ini relatif heterogen dari sisi komposisi penduduknya. Medan juga dipandang sebagai miniatur Indonesia karena bukan hanya keragaman suku bangsanya, tetapi juga penganut agama yang ada di sini. Di Medan orang sangat mudah menemukan tempat ibadah seperti masjid, gereja, maupun vihara. Bahkan kuil bagi umat Hindu terletak di daerah salah satu paling starategis di kota Medan hal tersebut menunjukkan keharmonisan yang ditunjukkan oleh masyarakat Medan dari dulu.

Penyebaran masyarakat yang cenderung memiliki cluster-cluster tersendiri yang sering diidentikkan dengan etnis yang berdiam di wilayah tersebut. Pusat-pusat konsentrasi masyarakat terbentuk biasanya oleh kegiatan ekonomi yang berkembang di daerah tersebut. Konsentrasi penyebaran penduduk biasanya didasarkan oleh jenis pekerjaan yang mereka lakukan membuat komunikasi yang kurang ideal dalam membangun kepercayaaan antara salah satu masyarakat dengan lainnya. Postur sosial yang terbentuk di dalam masyarakat di kota Medan kurang melebur antara etnis-etnis yang ada di dalamnya hampir tidak ada suku yang dominan di kota Medan sehingga membuat masing-masing etnis memperkuat identitas mereka. Masalah akan muncul ketika suatu etnis terlalu kuat untuk mempertahankan identitas kesukuannya sehingga menimbulkan reaksi yang kurang baik. Kota Medan memiliki masyarakat yang relatif heterogen sehingga sangat diperlukan kesadaran yang tinggi untuk menjaga kondusivitas wilayah ini. Pluralitas harus dianggap sebagai potensi, bukan ancaman terhadap disintegrasi bangsa selama perbedaan tersebut dianggap sebagai modal untuk membangun bangsa.

Kluster demografi penduduk kota Medan umumnya termasuk di pusat-pusat kegiatan ekonomi biasanya dihuni oleh orang-orang beretnis Tionghoa. Biasanya juga mereka berkelompok bertempat tinggal di komplek-komplek yang berdekatan dengan pusat kegiatan ekonomi. ${ }^{1}$ Bagi masyarakat menengah ke atas, alasan pengelompokan semacam kluster di beberapa wilayah yang seakan seperti lingkungan baru maupun kompleks perumahan yang memiliki petugas sekuriti didasarkan untuk alasan keamanan. Stigma masyarakat etnis tertentu kurang mau berbaur dengan masyarakat lainnya semakin membenarkan beberapa asumsi yang berkembang selama ini. Masyarakat di belahan bumi lainnya seperti

${ }^{1}$ Marilyn Porter, "Tita Marlita Hasan," dalam the Canadian Review of Sociology and Anthropology, 40.2, May 2003, h. 153-170. 
di Eropa Barat juga mengalami ketegangan sosial disebabkan perubahan demografi yang terjadi akan imigrasi orang-orang yang memiliki latar belakang yang berbeda. Tetapi ketegangan sosial bukan akibat penguasaan ekonomi lebih baik pada kedatangan dari kultur yang berbeda.

Dalam membaca hubungan sosial yang terjadi di dalam suatu masyarakat selalu terkait dengan banyak faktor yang mempengaruhinya. Selalu saja ada kelompok masyarakat yang merasa termarginalkan oleh situasi yang ada, baik itu secara kultur, ekonomi, maupun politik. ${ }^{2}$ Hal tersebut disebabkan pengalaman sosial yang dirasakan oleh masing-masing individu yang tergabung di dalamnya sangat berbeda antara satu dengan yang lainnya. Persepsi terhadap konsep marginal berbeda antara satu kelompok masyarakat dengan yang lainnya. Di Amerika misalnya kelompok minoritas merasa terpinggirkan karena kurang mendapat akses secara ekonomi dan politik. Kaum kulit hitam sering merasakan diskriminasi terhadap warna kulit dan hal ini masih kerap terjadi sehingga kasus penembakan seorang remaja kulit hitam di negara bagian Georgia oleh seorang polisi memicu gelombang protes bagi masyarakat kulit hitam di seluruh negeri. Rasa ketidakadilan bagi kaum kulit hitam bertambah terhadap sistem yang sudah ada setelah pihak pengadilan tingkat banding memutuskan bahwa petugas polisi yang menembak seorang remaja kulit hitam yang dicurigai sebagai seorang kriminal merupakan tindakan yang tidak bisa disalahkan demi menjaga ketertiban masyarakat. Persepsi orang kulit hitam yang sering dikaitkan dengan tindakan kriminal didasarkan atas angka kejahatan yang kerap terjadi di kalangan ini. Tindakan polisi yang menembak remaja kulit hitam suatu malam di suatu lingkungan yang rawan aksi kriminal dapat dibenarkan. Dalam hal ini, masyarakat minoritas tidak selalu dikaitkan dengan ketidak adilan secara ekonomi artinya dalam konteks Indonesia khususnya yang berada di Medan. Karena kelompok etnis minoritas seperti Tionghoa malah memiliki kekuatan secara ekonomi sehingga dalam hubungan sosial kemasyarakatan tampak sekali tidak seimbang antara kelompok-kelompok di dalam masyarakat itu sendiri. ${ }^{3}$

\section{Hubungan Individu dalam Masyarakat}

Dalam hubungan antara individu di kota metropolitan, masyarakat yang menjadi pelaku sosial terkadang memberikan respons yang berbeda dalam membentuk menjadi suatu komunitas. ${ }^{4}$ Masyarakat yang ingin meleburkan diri dengan komunitas lainnya menjadi satu (melting pot) cenderung berusaha meninggalkan kekhasan daerah yang selama ini

\section{h. 35 .}

${ }^{2}$ Edmund Husserl, The Idea of Phenomenology, terj. Lee Hardy (Dordrecht: Kluwer, 1999),

${ }^{3}$ George Ritzer, Modern Sociological Theory (New York: The McGraw-Hill Companies, Inc, 1996), h. 235.

${ }^{4}$ Feremenga Doglas Taruvinga, “Local Urban Development Stakeholders in Globalizing Context: Civil Society, Urban Governance and Urban Poverty in Harare, Zimbabwe" (Disertasi, University of California), h. 4-9. 
melekat di diri mereka dengan membawa identitas umum yang diterima semua pihak. Biasanya mereka ini adalah kelompok kecil dari masyarakat yang sudah lama bergaul di lingkungan yang sangat heterogen. ${ }^{5}$ Kelompok masyarakat ini biasanya lebih mementingkan identitas nasional saja sebagai satu-satunya simbol yang mengikat masyarakat secara umum. Faktanya mereka yang memiliki identitas sosial seperti ini kurang memiliki ikatan emosional yang kuat dengan etnis asal mereka karena dianggap tidak cinta terhadap kedaerahan.

Hubungan masyarakat di kota metropolitan pada umumnya hampir di setiap tempat masing-masing mengalami suatu tekanan dari luar sehingga merasa eksistensinya terancam dengan pihak lain. ${ }^{6}$ Karena itu, masing-masing kelompok masyarakat berusaha membentuk suatu aliansi persaudaraan atau kedaerahan yang dimaksudkan untuk memperkuat mereka menghadapi tantangan tersebut. Tampaknya aliansi kemasyarakatan yang terbentuk merupakan cerminan dari naluri manusia untuk tetap bertahan hidup, salah satu instrumen yang digunakan oleh masyarakat perkotaan dengan mengikatkan diri inter-personal dengan faktor kedaerahan. Dengan demikian ikatan emosional kedaerahan bukan hal utama, akan tetapi sebagai variabel pendukung untuk bisa survive dan berkembang.

Penggunaan bahasa daerah merupakan instrumen yang ampuh dalam membangun komunikasi sesama mereka dengan saling memperkuat jaringan. ${ }^{7}$ Identitas bahasa dianggap bisa membangun kekuatan sosial dalam menumbuhkan jaringan sosial yang kokoh. Sementara itu, dalam masalah penggunaan bahasa daerah di dalam masyarakat, terkadang suatu kelompok masyarakat agak reluctant dalam menggunakan bahasa tersebut kurang memberikan manfaat bagi dirinya. Tidak jarang langgam bahasa yang medok dapat lebih memberikan identitas yang kuat sehingga lebih meningkatkan komunikasi bagi mereka yang memiliki ikatan emosional dengan daerah tersebut. ${ }^{8}$ Memang terjadi dilema dalam semangat primordialisme yang terbawa dari lahir dengan semangat kebersamaan. Etika masyarakat perkotaan juga bukan hanya terkait dengan unsur kesukuan juga kesadaran terhadap lingkungan.

Beberapa negara telah mensosialisasikan mengenai bahaya sikap primordialisme yang terlalu fanatik. ${ }^{9}$ Fanatisme kesukuan maupun agama juga yang disinyalir telah mengotori pikiran banyak orang-orang yang berpikiran sempit. Kurang adanya kesadaran masyarakat

${ }^{5}$ Sasha Preece \& David Mellor, "Learning Patterns in Social Skills Training Program: an Exploratory Study," dalam Child \& Adolescent Social Work Journal, 26, 2 (April 2009), h. 87-101.

${ }^{6}$ Susan Pulliam \& Frederick Rose, "Metropolitan Life to Take Lead Role With First Executive's New York Unit," dalam Wall Street Journal, 6 Apr 1991.

${ }^{7}$ Abd Rahim, et al., "The Retention of Sinrilik Values in Teaching Local Language and Literature of Makassar," dalam Journal of Language Teaching \& Research, Vol. 6 Issue 5, 2015, h. 999-1009.

${ }^{8}$ Hamra Hasmiati, et al., "Designing an English Course Book for High School Students Based on 2013 Curriculum," dalam Journal of Language Teaching \& Research. Vol. 6 Issue 6, 2015, h. $1240-1249$.

${ }^{9}$ Frederick J. Crosson, "Fanatics, Politics and Religion Philosophy Today," 47.4 (Winter 2003), h. 441-447. 
terhadap bahaya fanatisme disebabkan kurangnya pengetahuan masyarakat terhadap dampak yang ditimbulkan oleh kebanggaan semu. ${ }^{10}$ Memang terjadi dilema dalam semangat primordialisme yang terbawa dari lahir dengan semangat kebersamaan. Etika masyarakat perkotaan juga bukan hanya terkait dengan unsur kesukuan juga kesadaran terhadap lingkungan.

Suatu penelitian yang baik tentunya memiliki signifikansi terhadap perkembangan masyarakat itu sendiri dalam arti dapat memberikan masukan ataupun solusi terhadap tantangan yang ada. Tantangan terbesar dari struktur masyarakat yang heterogen seperti di Indonesia adalah lahirnya semangat sekterian yang tidak terkendali akibat dari pemahaman primordialisme agama maupun kesukuan.

Perguruan tinggi merupakan salah satu garda terdepan yang dapat meningkatkan sumber daya manusia, bukan hanya meningkatkan kemampuan hard knowledge juga soft knowledge. Hard knowledge adalah kemampuan seseorang di bidang ilmu yang dikuasai dengan jalan peningkatan kemampuan skill. Sementara itu, soft skill lebih menekankan aspek yang lebih pada nilai-nilai integritas pribadi yang dimiliki seseorang, seperti loyalitas, kejujuran, maupun komitmen terhadap nilai-nilai yang disepakati bersama. Salah satu indikasi kemajuan suatu bangsa ketika keseimbangan terjadi antara kemampuan dalam bidang hard knowledge maupun soft knowledge sehingga membentuk karakter suatu bangsa. Nilainilai kejujuran, integritas, maupun komitmen yang tinggi merupakan hal yang sangat penting dijunjung dalam kehidupan ini. Karena hanya dengan demikian kemajuan yang telah tercapai akan dapat tetap dipertahankan. Pengalaman 1998 di Indonesia menunujukkan bahwasanya keberhasilan dalam pembangunan fisik akan mudah rapuh tanpa diiringi dengan pembangunan mental manusianya. Karena apapun alasannya manusia adalah aktor utama yang mengendalikan hasil-hasil pembangunan.

Hubungan komunikasi yang terjadi di dalam suatu komunitas tidak hanya terbatas dengan komunikasi verbal, tetapi bisa juga dengan non-verbal. Hal ini ditandai dengan saling memahami eksistensi masing-masing individu di dalam masyarakat. Tidak seperti masyarakat di pedesaan, intensitas hubungan komunikasi verbal relatif sering dilakukan. Akan tetapi, dalam masyarakat perkotaan yang memiliki tingkat heterogenitas yang sangat tinggi kontak antara masyarakat di dalamnya relatif jarang dilakukan. Terkadang perhelatan nasional seperti pemilihan umum yang membuat satu dengan lainnya berjumpa. Hal tersebut disebabkan kepentingan dalam hubungan aktivitas sehari-hari relatif berbeda. Belum adanya wadah semacam community gathering di dalam masyarakat yang memiliki heterogenitas yang tinggi dapat memicu ketegangan sosial. ${ }^{11}$ Kerusuhan 1998 yang dimulai di Medan dan merambat di kota-kota besar lainnya di Indonesia disebabkan terhambatnya komunikasi yang terjadi di dalam masyarakat yang memiliki tingkat pluralitas yang tinggi sehingga

\footnotetext{
${ }^{10}$ Gwen Potts, "Fanatism, Not Religion to Blame," dalam Edmonton Journal, 17 September 2010, h. 17.

${ }^{11}$ Hans G Kippenberg, "Phoenix from the Ashes: Religious Communities Arising from Globalization," dalam Journal of Religion in Europe, Vol. 6 Issue 2, 2013, h. 143-174.
} 
mudah dipicu oleh persoalan lainnya seperti kesenjangan ekonomi. Pemerintah tampaknya belum menganggap penting pembentukan community gathering di kota-kota besar mungkin saja belum dianggap urgen karena diasumsikan dapat ditangani oleh komunitas setempat. Identitas sosial suatu komunitas dapat dilihat dari berbagai hal baik itu bentuk fisik secara umum, tempat ibadah, bentuk bangunan rumah, penampilan berbusana, penggunaaan nama marga atau lainnya yang senada. ${ }^{12}$

Di Indonesia, umumnya kuantitas tempat ibadah bisa menandakan identitas komunitas yang ada di dalam masyarakat. Sebab pusat konsentrasi masyarakat pada umumnya selalau menyertai tempat ibadah sebagai simbol keberadaan masyarakat tertentu. Hal tersebut dapat dengan mudah bagi seseorang untuk berasumsi berapa jumlah penduduk suatu kelompok masyarakat hanya dengan melihat berapa jumlah tempat ibadahnya. Terkadang juga suatu kelompok masyarakat menggunakan simbol religius tertentu sebagai pertanda identitas kelompok masyarakatnya. Hal itu ingin mempertegas bukan hanya eksistensinya di dalam masyarakat, tetapi juga menjadi pesan bagi mereka yang memiliki persepsi identitas yang sama. Ada juga kelompok masyarakat yang menggunakan simbol berbusana sebagai bentuk identitas diri di dalam masayarakat, seperti pengunaan jilbab, kupiah, serban bagi masyarakat Muslim atau turban bagi masyarakat Tamil. Penggunaan simbol berbusana dalam masyarakat menunjukkan identitas diri suatu kelompok masyarakat. Hal tersebut merupakan bentuk dari komunikasi non-verbal kepada pihak lain tentang diri mereka. ${ }^{13}$ Ada juga identitas diri yang dapat diungkapkan dengan penggunaan marga atau gelar kebangsawasan yang merupakan suatu kelaziman di dalam masyarakat. Ini merupakan refleksi sinyal untuk melakukan ikatan emosional dengan mereka yang terkait. Ini merupakan semacam pernyataan diri sebagai keturunan bangsawan yang terhormat. ${ }^{14}$

Semua identitas diri yang diungkapkan di atas dimaksudkan untuk mempertegas eksistensi diri yang ingin diperlakukan sesuai dengan nilai-nilai sosial yang dianutnya. Oleh karena itu tidak tertutup kemungkinan adanya ketegangan sosial yang terjadi di masyarakat disebabkan nilai sosial yang dianut berbeda antara kelompok masyarakat. Dalam hal ini, perlu adanya kesadaran dari masing-masing kelompok masyarakat untuk menghargai nilai sosial yang dianut mereka, misalnya sangat tidak santun memperjual belikan makanan atau masakan babi yang diharamkan oleh pihak Muslim di tempat yang lazim dilewati oleh banyak orang. Sebab itu, perlu ada kebijakan dari anggota komunitas masyarakat untuk membuat kegiatan tersebut agak tersamarkan agar terjalin hubungan sosial yang lebih

\footnotetext{
${ }^{12}$ Nico Schutte \& Nicolene Barkhuizen, "Electronic Journal of Knowledge Management," Agustus 2015, Vol. 13, Issue 2, h. 130-141.

${ }^{13} \mathrm{Hang} \mathrm{Du}$, "American College Students Studying Abroad in China: Language, Identity, and Self-Presentation," dalam Foreign Language Annals, June 2015, Vol. 48 Issue 2, h. 250-266.

${ }^{14}$ Üzeyir Ogurlu, "Relationship between Cognitive Intelligence, Emotional Intelligence and Humor Styles," dalam International Online Journal of Educational Sciences, Juni 2015, Vol. 7 Issue 2, h. 15-25.
} 
harmonis karena pihak lain merasa dihargai nilai-nilai sosial yang dianutnya. ${ }^{15}$ Hubungan sosial suatu kelompok masyarakat semakin bisa sejalan bila nilai-nilai sosial yang dianut tetap bisa eksis atau diakomodir di dalam komunitas yang lebih luas. Diperhatikan lebih lanjut, terkadang ada kelompok masyarakat yang menampilkan identitas diri dari kelompok masyarakat lainnya. Hal itu ditandai dengan munculnya identitas kesukuan di dalam organisasi yang tidak ada hubungannya dengan etnitas. Sementara itu, penggunaan identitas marga di dalam suatu organisasi masyarakat maupun partai politik memiliki dimensi lain.

Ada beberapa penelitian terdahulu yang relevan dengan tulisan ini karena masalah ini begitu urgen untuk dibahas secara ilmiah. Salah satu di antaranya ialah Simon Montlake dalam karyanya yang berjudul Indonesia Stumbles Over Faith Pluralism. ${ }^{16}$ Digambarkan dalam penelitiannya tentang adanya infiltrasi transnasional Islam garis keras yang berusaha merubah wajah Islam di Indonesia yang moderat dan toleran menjadi Islam berhaluan keras.

\section{Komunikasi dan Social Identity Masyarakat}

Identitas sosial pada suatu masyarakat muncul dilatar belakangi oleh beberapa faktor yang mempengaruhinya. Faktor alam, kondisi sosial, maupun hal yang menyangkut dengan SARA dapat membentuk identitas sosial yang terbentuk. Pada masyarakat homogen, identitas sosial yang terbentuk biasanya dimotori oleh tokoh-tokoh yang memiliki reputasi sebagai pihak yang tetap mempertahankan tradisi yang telah berlangsung sejak lama. Peran pemangku adat sangat menonjol sebagai figur yang dianggap paling otoritatif dalam memertahankan nilai-nilai budaya sebagai wujud dari identitas sosial pada masyarakat itu. Seiring dengan perkembangan zaman, pengaruh kekuatan ekonomi juga merambah di ranah simbol-simbol identitas sosial, sehingga pemodal yang kuat di dalam masyarakat juga mencoba merebut pengaruh dengan menggandeng mereka yang dianggap sebagai figur utama yang mempertahankan identitas kelompok. ${ }^{17}$ Hampir setiap kelompok di masyarakat berusaha untuk lebih menonjolkan identitas kelompok sosial mereka akibat dari adanya ancaman pengaruh global yang dianggap dapat menghilangkan identitas sosial yang telah eksis sejak lama. Identitas sosial tidak bisa dihilangkan dalam kehidupan sosial, walaupun dalam tataran tertentu, perilaku dari masing-masing individu yang berasal dari identitas sosial yang berbeda ada yang mudah diidentifikasi atau agak samar. Perilaku komunikasi identitas sosial bagi mereka yang berbeda secara fisik seperti warna kulit akan lebih mudah dideteksi di dalam masyarakat karena tampilan fisik yang mudah dikenali

${ }^{15}$ Tsirogianni S \& Sammut G, "Transitivity Analysis: a Framework for the Study of Social Values in the Context of Points of View," dalam the British Journal of Social Psychology, September, Vol. 53 (3), 2015, h. 541-556.

${ }^{16}$ Khaled Abou El Fadl, The place of Tolerance in Islam (Boston: Beacon, 2002), h. 7-9.

${ }^{17}$ Amanda Keddie, "Political Justice, Schooling and Issues of Group Identity," dalam Educational Philosophy \& Theory. Maret 2014, Vol. 46 Issue 3, h. 311-323. 
identitas sosial mereka. Gestald yang sudah terbentuk pada masyarakat tertentu yang memiliki identitas sosial yang khas berbeda biasanya muncul akibat pengalaman sejarah yang berkaitan dengan politik. Akan tetapi, berbeda dengan komunitas masyarakat yang secara umum tidak memiliki perbedaan fisik, maka identitas sosial biasanya berasal dari agama maupun suku. Identitas masyarakat yang berada di dalam masyarakat yang heterogen lebih terpolarisasi kepada agama dan suku, sehingga identitas sosial yang terwakili dari agama dan suku ini lebih pada melekatkan sisi emosi spiritual dibandingkan identitas sosial yang terbentuk dari pengalaman budaya. Karena individu yang menyandarkan identitas sosial yang berasal dari agama agak kurang memiliki sense terhadap persepsi nilai-nilai kebajikan lokal yang dipahami individu lain dalam identitas sosial tersebut. Fakta menunjukkan bahwa banyak kasus di pemilihan kepala daerah dimana masih kuatnya identitas sosial suku dalam menjaring pemilih, sehingga menjadi membuktikan bahwa peran sosial identitas kesukuan masih sangat kuat melekat di masyarakat Indonesia. Hal tersebut merupakan refleksi adanya kekuatan sosial yang terkandung dari ikatan primordialisme yang merupakan keniscayaan yang terjadi dalam kehidupan sosial

Hubungan sosial antara individu maupun kelompok masyarakat memiliki variabel yang sangat rumit sehingga tidak mudah menggambarkan secara gamblang. Karena pada dasarnya individu yang hidup di masyarakat memilki konsep nilai yang dianutnya masing masing, akan tetapi nilai tersebut harus tunduk pada nilai agama maupun identitas sosial yang telah disepakati. ${ }^{18}$ Akan tetapi, masing-masing individu ini tetap saja berusaha untuk melakukan ekspansi sehingga mempengaruhi nilai-nilai yang ada di dalam kelompoknya. Tidak mengherankan, sering sekali terjadi perubahan terhadap persepsi nilai-nilai identitas yang telah disepakati selama ini akibat dari pengaruh-pengaruh variabel-variabel kehidupan yang mempengaruhi kehidupan sosial. Seorang individu yang tinggal di Medan akan memiliki variable kehidupan yang mempengaruhi identitas diri yang melekat padanya tergantung asal kampung halamannya, suku, agama, maupun ekonomi, serta kehidupan di rumah tangga. Agak lebih sulit melakukan kluster pola identitas sosial yang terjadi pada masyarakat yang memiliki latar belakang variable kehidupan yang berbeda dengan kelompok mayarakat yang relatif berasal dari pola variable yang sama. Akan lebih mudah mengatur serta mengarahkan suatu masyarakat yang relatif memiliki pola variabel yang sama, dalam artian kehidupan sosial yang memiliki latar belakang sosial maupaun keagamaan yang sama (homogen). Itu sebabnya kenapa di wilayah-wilayah tertentu yang cenderung homogen tingkat keteraturan masyarakatnya baik dari segi berlalu lintas maupun kebersihan cenderung lebih baik di banding kota-kota yang metropolitan seperti Jakarta, mapun Medan. Karena kedua kota di atas merupakan gambaran dari masyarakat yang sangat heterogen bahkan penduduk pribuminya sudah tersingkir sebagai pemain utama di masyarakat. ${ }^{19}$ Sebab

${ }^{18}$ Ben Lovell, "We are a Tight Community': Social Groupsand Social Identity in Medical Undergraduates," dalam Medical Education. Oktober 2015, Vol. 49, Issue 10, h. 1016-1027.

${ }^{19}$ Gavrilets S., "Philosophical Transactions of the Royal Society of London," dalam Biological Sciences, Desember 2015, Vol. 370. 
itu, kesemrautan, maupun kebersihan merupakan salah satu tolok ukur dalam melihat betapa teratur suatu masyarakat sehingga akan lebih sulit didapatkan di masyarakat yang tingkat heteroginitasnya tinggi yang menyebabkan tersingkirnya masyarakat pribumi (tuan rumah ) di panggung sosial. Surabaya merupakan kota metropolitan, akan tetapi tingkat hetrogenitas masyarakatnya tidak begitu tinggi bahkan pribumi tetap bisa eksis di kehidupan sosial sehingga kota ini agak lebih mudah diatur dalam hal kebersihan. Karena orang pribumi tetap memiliki peran yang penting dalam kehidupan sosial, mereka yang berasal dari luar sebagai pendatang memiliki patron dalam bermasyarakat di daerah tersebut. ${ }^{20}$ Lain halnya di daerah lain di Medan sepertinya masih sangat gamang dalam mengekpresikan identitas sosial yang dimilikinya karena masih belum jelasnya patron nilai-nilai identitas sosial yang hendak diusung. Hal tersebut disebabkan latar belakang nilai-nilai lokal yang tidak jelas lantaran daerah ini merupakan ekses dari pengembangan Kota Medan. Dalam perjalanannya, banyak orang-orang yang melakukan perpindahan pada 50 tahun yang lalu yang membentuk komunitas tersendiri. Dalam perkembangannya, Medan mengalami berbagai perubahan pola kluster tempat tinggal, akibat dari kepindahan masyarakat Muslim yang kemudian digantikan oleh kelompok masyarakat etnis Tionghoa. Masyarakat Tionghoa di Medan tidak seperti di kota-kota lainnya di Indonesia yang menggunakan bahasa lokal dalam kehidupan seharihari. Akan tetapi, masyarakat Tionghoa di Medan mereka selalu saja menggunakan bahasa Hokien yang berasal dari Tiongkok dalam kegiatan sosial sesama mereka. ${ }^{21}$

Masyarakat di Medan saat ini sedang mengalami metamorfosa sosial menuju masyarakat tanpa patron identitas sosial. Hal tersebut akibat dari tidak adanya simbol identitas sosial yang dijadikan patron bagi kelompok masyarakat di sana. Identitas sosial yang ditampilkan hampir tidak memiliki kekhasan tersendiri sehingga dikhawatirkan kurang bisa mengikat antara kelompok-kelompok sosial yang ada di dalamnya. Satu-satunya media berkumpul warga masyarakat di sana secara komprehensif hanya ketika peristiwa pemilihan umum baik itu pemilihan presiden maupun kepala daerah. Kurangnya program yang diinisiasi pemerintah maupun warga dalam mempertemukan masyarakat memiliki latar belakang yang berbeda. Hal ini memberi kontribusi semakin tidak berkualitasnya komunikasi antara masyarakat. ${ }^{22}$ Sebab itu, sikap apatisme yang terjadi semakin tinggi yang akhirnya dapat meruntuhkan sendi-sendi perekat sosial di dalam masyarakat.

Di dalam masyarakat Barat yang mengagungkan prinsip-prinsip individual yang

${ }^{20}$ Stanton Wortham \& Catherine Rhodes, "Life as a Chord: Heterogeneous Resources in the Social Identification of One Migrant Girl," dalam Applied Linguistics, Desember 2013, Vol. 34 Issue 5, h. 536-553.

${ }^{21}$ Chang-Yau Hoon, "Multicultural Citizenship Education in Indonesia: The Case of a Chinese Christian School," dalam Journal of Southeast Asian Studies, Oktober 2013, Vol. 44, Issue 3, h. 490-510.

${ }^{22}$ Saeed Ahmad, "Role of Socioeconomic Status and Political Participation in Construction of Apathy Among Youth," dalam Journal of Human Behavior in the Social Environment, NovemberDesember 2015, Vol. 25, Issue 8, h. 801-809. 
tinggi sekalipun, mereka melakukan banyak program kegiatan yang diinisiasi oleh pemerintah maupun lembaga swadaya masyarakat untuk menciptakan semacam program yang memungkinkan masyarakatnya melakukan interaksi sosial yang lebih tulus tanpa dilatarbelakangi kepentingan ekonomi maupun politik praktis. ${ }^{23}$

Ada dua opsi yang mungkin ditawarkan dalam kegiatan-kegiatan yang berkaitan dengan pemberdayaan masyarakat, yaitu dengan melakukan melting pot dan non-melting pot. Keduanya memiliki keunggulan maupun kelemahannya masing-masing. Pola melting pot biasanya diterapkan pada kelompok masyarakat yang memiliki latar belakang yang sangat berbeda sehingga dibutuhkan satu bentuk identitas baru yang mengikat semua elemen masyarakat yang ada di dalamnya. Amerika mengadopsi sistem melting pot yang dilatarbelakangi oleh semangat menumbuhkan nasionalisme baru karena warganya berasal dari berbagai bangsa yang melakukan imigrasi ke sana. Prinsip patriotisme yang dibangun berusaha untuk menghilangkan semangat primordialisme yang dibawa oleh masingmasing individu warganya dengan satu identitas kebangsaan sebagai warga negara Amerika. Akan tetapi, negara Kanada, tetangganya, lebih bersikap akomodatif terhadap nilai-nilai primordialisme warganya yang juga berasal dari berbagai bangsa di dunia. Kanada berusaha menciptakan masyarakat memberi kebebasan kepada warganya untuk tetap mempertahankan identitas asal warganya selama tidak mengganggu kepentingan nasional secara umum. $^{24}$

Tidak mengherankan di Kanada banyak sekali nama-nama kota yang namanya identik dengan asal warga yang dominan di daerah tersebut yang sama persis dengan nama-nama di negara asalnya. Festival warga-warga yang berasal dari Eropa lazim diadakan di kotakota yang ada di Kanada sebagai indikasi sikap akomodatif dari pemerintah di sana yang tetap membebaskan warga berekspresi dengan simbol-simbol primordialisme yang melekat pada warganya. Untuk kasus di Medan, tampaknya pemerintah masih gamang dalam menerapkan pola yang cocok dalam menggambarkan identitas sosial masyarakat Medan secara umum. Seharusnya ada keberanian dan kemauan tentang identitas sosial yang diambil dari heteregonitas masyarakat dengan menjadikan satu dari sekian kelompok masyarakat yang dijadikan identias sosial secara konsisten. Bagi masyarakat di Pulau Jawa, terutama etnis dominannya memang berasal dari kelompok lokal, dan penerapan bahasa Jawa di hari-hari tertentu dalam jam kerja dinilai sebagai usaha yang baik dalam mempertahankan nilai-nilai lokal tanpa ada satu pun yang mempertentangkannya.

Di sisi lain, bagi masyarakat Medan, tampaknya setiap Walikota belum memiliki konsep yang jelas dalam menentukan identitas sosial yang ingin ditampilkan di dalam masyarakat. Realitas etnis Melayu yang dianggap sebagai kelompok masyarakat tuan rumah dengan

\footnotetext{
${ }^{23}$ Nataly Socci, "Turkish Neigboughood Policy and EU Membership: Squering the Circle of Turkish Foreign Policy," dalam International Journal, 67.1 (Winter 2011/2012), h. 65-80.

${ }^{24}$ Elke Winter, "Rethinking Multiculturalism After its "Retreat": Lessons From Canada," dalam American Behavioral Scientist, May 2015, Vol. 59, Issue 6, h. 637-657.
} 
peninggalan beberapa bangunan kerajaan Melayu seperti Istana Maimun dan Masjid Raya. Masyarakat Melayu yang dari segi jumlah dan penguasaan ekonomi masih sangat minim di Kota Medan seharusnya mendapatkan hak yang lebih untuk dijadikan patron sosial bagi kelompok-kelompok masyarakat lainnya. Akan tetapi, selama bertahun-tahun lamanya identitas kota Medan identik dengan suku Batak dan sekarang sudah mulai bergeser ke etnis Tionghoa. Selama ini Kota Medan selalu diidentikkan dengan suku Batak sehingga membuat semakin rancu semangat identitas sosial kota ini selama berpuluh-puluh tahun lamanya. Karakter suku Melayu tidak seperti suku Betawi di Jakarta maupun saat ini yang telah menjadi kelompok minoritas dan relatif terpinggirkan, akan tetapi identitas sosial Kota Jakarta tetap menjadikan adat budaya Betawi sebagai patron sosial yang harus diikuti maupun dipatuhi oleh pemerintah maupun masyarakat pendatang di sana. ${ }^{25}$ Sementara ini suku Melayu yang seyogyanya sebagai tuan rumah di kota Medan selama ini kurang begitu reaktif bahkan cenderung mengalah dengan tekanan kaum pendatang. Akhirnya mereka dipinggirkan dalam pentas sosial, ekonomi, dan politik. Hal tersebut disebabkan kurang terkoordinasi dengan baik usaha dalam memobilitas kekuatan sumber daya yang ada dalam komunitas tersebut. Ada kesan bahwa mereka kalah bersaing dengan kaum pendatang lainnya sehingga menyingkir di daerah-daerah pinggiran pantai. Patron sosial sebagai tuan rumah di tanah Melayu selama ini perlu adanya keberpihakan dari pemerintah khususnya dalam upaya mempertahankan identitas utama dalam kebudayaan Melayu di kota Medan. Usaha ini diharapkan dapat menjadi penyeimbang dari penetrasi budaya dari kelompok-kelompok masyarakat yang tinggal di kota Medan.

Islam merupakan agama yang rahmat bagi seluruh alam. Sebab itu, Islam sebagai ideologi pada dasarnya tidak hanya baik untuk orang Muslim, akan tetapi juga bermanfaat kepada non Muslim. Hal tersebut dapat dilihat dalam Piagam Madinah yang merupakan karya pertama manusia yang membuat hubungan antara masyarakat baik dari segi toleransi maupun persamaan hak. Kemitraan yang dimaksud di sini ialah kemitraan simbiosis mutualisme, saling menguntungkan antara kedua belah pihak, tanpa ada pihak yang merasa dirugikan dan tentunya tidak merusak alam. Hal ini telah dilakukan oleh Nabi Muhammad dalam membangun kemitraan dengan masyarakat non-Muslim di Madinah dalam menjaga persatuan dan kesatuan dari agitasi pihak luar yangmeliputi semua sektor kehidupan. Dalam konteks membangun kemitraan dengan pihak luar, tampaknya langkah yang dilakukan Nabi Muhammad cukup bijak dengan melakukan konsolidasi di kalangan internal sebelum membangun kemitraan sosial dengan pihak luar.

Dalam konteks kemitraan sosial yang terlihat selama ini termasuk yang terjadi di Medan, secara jelas posisi yang lemah sekali tampak mulai terpinggirkannya wilayahwilayah tertentu yang selama ini didominasi umat Islam. Akan tetapi, sekarang kelompok

${ }^{25}$ Paula Gerstenblatt \& Dorie J. Gilbert, "Framing Service Learning in Social Work: An Interdisciplinary Elective Course Embedded within a University-Community Partnership," dalam Social Work Education, Desember 2014, Vol. 33, Issue 8, h. 1037-1053. 
minoritas. Untuk meningkatkan bargaininng position umat Islam, langkah yang harus dilakukan adalah dengan melakukan konsolidasi kekuatan sumber-sumber ekonomi juga mental spiritual. ${ }^{26}$ Konsolidasi pemanfaatan ekonomi ialah dengan menggunakan segala potensi secara optimal. Dengan melakukan mobilisasi kekuatan ekonomi umat Islam tentunya kemakmuran umat Islam betul-betul bisa diharapkan. Sementara itu, konsolidasi kekuatan mental spiritual yang dimaksud di sini ialah dengan membangun integritas kepribadian yang tinggi tentunya dengan menanamkan sifat kejujuran. Kejujuran merupakan kekuatan mental spiritual yang pertama sekali ditanamkan Nabi kepada para sahabatnya. Karena sifat ini sangat penting dalam membangun kekuatan spiritual seorang Muslim. Selama pemerintahan Orde Baru terbukti pembangunan fisik tidak cukup dalam membangun suatu bangsa. ${ }^{27}$ Dapat dilihat betapa rapuhnya pondasi ekonomi bangsa sehingga membawa bencana krisis ekonomi pada tahun 1997, juga menimbulkan krisis-krisis lainnya di negeri ini. Kejujuran merupakan refleksi kepatuhan kepada Allah karena segala aktivitasnya merasa diawasi oleh-Nya, mereka yang telah bersikap jujur dapat dilihat dari aktivitasnya seharihari yang selalu memberi manfaat bagi orang lain.

Dalam membangun hubungan sosial yang lebih harmonis, dialog merupakan suatu keniscayaan yang harus dilakukan karena semakin intens dialog yang dilakukan akan semakin mempererat hubungan individu-individu di dalam masyarakat. Media dialog antara warga di Medan selama ini kurang begitu efektif. Belum ada disain yang serius dari pemerintah untuk membuat sarana dialog bagi warganya. Selama ini sarana dialog warga di Medan masih bersifat inisiatif dari kalangan internal masing-masing. Biasanya dialog yang dilakukan di tempat-tempat rumah ibadah masing-masing bagi pemeluknya. Bagi umat Islam dialog yang terjadi dengan mengikuti acara wirid malam Jumat bagi kaum bapak dan hari selasa siang bagi kaum ibu. Artinya, dialog warga di Medan masih di kalangan internal. Sebenarnya diperlukan sekali dialog lintas agama, maupun budaya sehingga meningkatkan saling pengertian di dalam masyarakat. Hasil investigasi penulis kepada warga di Medan masingmasing pihak merasa dikucilkan ataupun kurang diperhatikan oleh pihak pemerintah. Bagi golongan masyarakat Tionghoa banyak diantara mereka yang merasa kondisi lingkungan masih belum aman dan nyaman sehingga dapat dilihat dari rumah-rumah masyarakat Tionghoa hampir semua ditutup kerangkeng besi. Sementara itu, banyak kalangan warga pribumi yang merasa pemerintah dan aparatur di dalamnya masih belum memberikan dukungan yang kuat terhadap golongan ekonomi lemah. Gambaran di atas dapat memberi diskripsi yang jelas betapa hubungan individu masyarakat Medan belum terintegrasi dengan baik. Sebenarnya kondisi masyarakat heterogen bisa jauh lebih maju dibandingkan dengan masyarakat homogen. Hal tersebut dapat dilihat dari realitas sosial di seluruh dunia, karena

${ }^{26}$ Michael J. Piore \& Paul Osterman, Economy in Society: Essays in Honor of Michael J. Piore (Cambridge, Mass.: The MIT Press, 2013).

${ }^{27}$ Andreas Ufen \& Bunte Marco, Democratization in Post-Suharto Indonesia (London: Routledge, 2009). 
sudah menjadi sunnatullah manusia mencari penghidupan yang lebih baik. Terkadang dalam perjuangan mereka timbul persaingan, tentunya tingkat persaingan di masyarakat heterogen lebih tinggi dibanding dengan masyarakat homogen. Akan tetapi, apabila hal tersebut ditangani dengan baik dengan menciptakan kondisi yang kondusif bagi semua pihak, bukan persaingan yang didasarkan oleh prinsip kanibalisasi, maka hal tersebut sangat baik. Kenyataan umat Islam dalam posisi marginal merupakan refleksi kemunduran Umat Islam secara global karena memandang ajaran Islam masih secara parsial bukan komprehensif sehingga menyulitkan diri sendiri.

Ada hal yang pokok dalam hal membangun kemitraan dengan kalangan non-Muslim, yaitu tetap mengacu pada konsep agamamu untukmu, dan agamaku bagiku. Ayat tersebut menegaskan hubungan yang tegas antara Muslim dengan non-Muslim dalam membangun kemitraan. Sebagai sesama manusia memang sudah menjadi sunnatullah manusia itu saling membutuhkan antara satu dengan yang lain, tidak memandang agama, suku, maupun rasnya. Islam tidak pernah melarang untuk menjalin kemitraan dengan non muslim diluar masalah akidah.

Kemitraan yang dimaksud ialah kemitraan simbiosis mutualisme, yaitu saling menguntungkan antara kedua belah pihak, jangan ada salah satu pihak yang merasa dirugikan. Karena itu, kemitraan yang hendak dibangun dalam prinsip Islam haruslah berlandaskan Islam sebagai rahmah li al-ấlamîn, rahmat bagi sekalian alam. Jadi, kemitraan yang Islam itu ialah kemitraan yang saling menguntungkan antara kedua belah pihak dan tidak ada unsur merusak alam. Hal ini dapat dilihat kemitraan yang dilaksanakan zaman Nabi Muhammad SAW. Dengan berbagai kalangan non-Muslim di Madinah dalam menjaga persatuan dan kesatuan warga Madinah dari agitasi pihak luar, ataupun kemitraan yang dilakukan oleh Nabi beserta sahabat dengan pihak Yahudi dalam bidang perdagangan yang menghasilkan antara transaksi jual beli antara kedua belah pihak.

Dalam konteks sekarang, banyak dilihat kemitran-kemitraan yang telah dibangun baik itu berskala nasional, regional maupun berskala internasional. Seperti forum komunikasi antara umat beragama, ASEAN, ataupun APEC maupun PBB. Kemitraan di atas boleh-boleh saja bahkan sudah menjadi keharusan, akan tetapi yang perlu diingat kemitraan yang islami tersebut harus tidak ada pihak yang merasa dirugikan maupun terdapat unsur merusak.

Umat Islam dewasa ini dalam membangun kemitraan dengan pihak non-Muslim harus meniru bagaimana Nabi Muhammad SAW. Dalam membangun kemitraan, Nabi Muhammad SAW. beserta sahabat telah melakukan kemitraan dengan pihak non-Muslim (sehingga menghasilkan karya momumental yang disebut Piagam Madinah), sehingga terlebih dahulu melakukan konsolidasi ke dalam. Maksudnya ialah Nabi Muhammad SAW. melakukan mobilisasi segala potensi kaum Muslim terlebih dahulu. Bila kekuatan kaum Muslim sudah nampak, maka bergaining position atau nilai tawar pihak kaum Muslim pun tinggi, sehingga seseorang tidak bisa didikte oleh pihak lain.

Lihat saja posisi umat Islam dalam menjalin kemitraan dengan pihak non-Muslim dewasa 
ini baik secara nasional, regional, maupun internasional sering sekali menjadi pihak yang dipinggirkan bahkan terkesan terzalimi dengan melanggar hak asasi manusia dalam mengembargo banyak negara Islam atas nama PBB. Bahkan menyerang tanpa mandat PBB dengan alasan ada senjata pemusnah massal yang belakangan tidak terbukti, atau dengan lantangnya Israel tidak mau menyerahkan wilayah-wilayah Arab seperti Palestina dan Syria bahkan masih menjajah Palestina sampai sekarang. Padahal PBB telah mengeluarkan resolusi agar Israel keluar dari wilayah-wilayah tersebut, atau pertentangan antara negara-negara maju dan berkembang di APEC karena pihak negara berkembang merasa dirugikan oleh negaranegara maju dalam hal, misalnya, tarif bea masuk produk pertanian.

Independensi penegak hukum merupakan hal yang didambakan oleh setiap warga negara di manapun berada, setelah pengalaman sejarah di berbagai wilayah betapa hukum tidak berdaya ketika berhadapan dengan penguasa. ${ }^{28}$ Independensi penegakan hukum sangat terasa manfaatnya ketika aparatur penegak hukum yang memiliki integrasi yang tinggi. Kejujuran merupakan hal yang sangat krusial yang harus dimiliki oleh aparat penegak hukum, akan tetapi dalam realitas di masyarakat kejujuran dan keadilan masih merupakan barang langka yang sulit ditemukan. ${ }^{29}$ Tidak jarang independensi penegakan hukum menciptakan ruang otoriter baru di dalam dunia penegakan hukum itu sendiri. Sistem Trias Politika yang dianut oleh kebanyakan bangsa di dunia ternyata banyak menciptakan ruang ketidakadilan karena kurangnya kontrol secara optimal terhadap aparatur yang ada di dalamnya. Pengalaman sejarah sebelum lahirnya sistem pemerintahan modern (Trias Politika) penegakan hukum tidak terletak pada sistem di dalam peradilan atau penegakan hukum itu sendiri. Akan tetapi, lebih banyak didasari oleh political will dari penguasa atau raja sehingga hukum menjadi hal yang tidak pasti karena tergantung kondisi mood penegakan dari penguasa. Kisah keadilan yang terjadi biasanya selalu dikaitkan dengan figur raja yang menegakkan keadilan bukan pada sosok hakim atau aparatur penegak hukum. Hal tersebut terjadi disebabkan sistem penegakan hukum pada masa klasik relatif sangat tergantung pada sosok penguasa.

Sebenarnya dalam sejarah Islam terutama pada masa pemerintahan 'Umar ibn Khattâb sudah mulai dilakukan usaha untuk memisahkan antara wilayah pemerintahan dan kehakiman. Bahkan hampir tidak pernah dijumpai di dalam sejarah klasik manapun di luar Islam seorang penguasa bisa kalah dalam berperkara dengan seorang rakyat biasa yang juga minoritas (Yahudi). Langkah besar yang dilakukan oleh 'Umar merupakan refleksi dari lompatan besar dari pemikiran yang sangat maju yang lintas masa pada waktu itu. ${ }^{30}$ Sayangnya, langkah besar tersebut tidak ditangkap oleh penguasa-penguasa Islam setelah masa Khulafaur-

\footnotetext{
${ }^{28}$ Mrinmay Deb, "Assortment Planning of Vertically Differentiated Products Under Consumer Choice," dalam The Pennsylvania State University, 2013.

${ }^{29}$ Max Harris, "The Rule of Law in Private Law: A New Animating Ideal for Employment Law?," dalam New Zealand Journal of Employment Relations, 37.1, 2012, h. 44-59.

${ }^{30}$ Husni Adham Jarror, Pergilah ke Jalan Islam: Sebuah Paket Metode Gerakan Islam Masa Kini, terj. Abu Fahmi (Jakarta: Gema Insani Press, 1989)
} 
Rasyidin. ${ }^{31}$ Keberanian seorang hakim yang memenangkan kasus seorang dari golongan minoritas terhadap seorang pengusa yang wilayahnya melebihi kekusaan Kerajaan Romawi dan Persia pada waktu itu harus dilihat dari berbagai aspek. Sosok integritas setiap aparatur akan lahir bila sistem yang menuntut hal tersebut juga sudah terbangun. Sudah menjadi suatu kelaziman sistem akan terbangun bila konsistensi dari penguasa untuk mewujudkan komitmen penegakan hukum itu sendiri. Konsistensi 'Umar dalam penegakan hukum dengan berusaha membuat jarak antara dirinya dengan wilayah kehakiman.

Independensi kehakiman walaupun dimaksudkan untuk memberi ruang pada hakim sebagai tembok terakhir keadilan, akan tetapi sering dimaknai layaknya bebas tanpa kontrol dari pihak lain. Merupakan hal yang tidak dapat dipungkiri pihak-pihak terkait dengan masalah hukum akan berusaha meraih akses ke aparatur penegak hukum agar masalah yang terkait dengan mereka akan bisa diatur sesuai dengan keinginan mereka. Hal tersebut bisa menciptakan godaan untuk melakukan pelanggaran hukum dari penegakan hukum itu sendiri. ${ }^{32}$ Permasalahan hukum yang terjadi ibarat benang kusut yang sulit dicari ujung pangkal dari masalah yang terjadi di dalam masyarakat. Sering sekali lontaran yang ada disebabkan oleh sistem hukum yang tidak jalan di negeri ini. Di sisi lain, sikap frustasi terhadap penegakan hukum yang ada disebabkan usaha perbaikan terutama penambahan lembaga terus juga dibentuk untuk menegakkan hukum. Akan tetapi, hal tersebut kurang begitu berhasil diwujudkan karena penambahan lembaga-lembaga penegakan hukum maupun pengawasan tidak mengurangi kebocoran anggaran maupun kolusi yang terjadi di dalamnya.

Masalah utama dalam penegakan hukum di Indonesia tidak terletak pada minimnya aparat maupun lembaga penegakan hukum maupun pengawasan, akan tetapi root problem yang terjadi adalah kesadaran. ${ }^{33}$ Seorang aparat penegak hukum seyogyanya diisi oleh mereka yang bukan hanya memiliki penampilan fisik yang ideal juga harus memiliki kapasitas emosi dan intelektual serta track record yang bagus di atas rata-rata. Karena masyarakat merupakan refleksi dari penegakan hukum yang dilakukan oleh aparatur hukum. ${ }^{34}$ Karena itu penegakan hukum harus dimulai dari aparatur penegak hukum itu sendiri. Hukum tidak akan mungkin bisa berjalan dengan baik bila aparaturnya tidak memiliki integrasi yang tinggi walaupun sebaik apapun produk hukum yang dihasilkan. Untuk menyikapi kondisi masyarakat yang masih belum teratur dalam berperilaku sesuai aturan yang ada harus diubah kesadaran sosial bersamanya. ${ }^{35}$ Masalah utama tidak terletak pada masyarakat

${ }^{31}$ Umar Sulaiman al-Asyqar, al-Rasûl wa al-Risâlah (Amman: Dar al-Nafais, 2002).

${ }^{32}$ Roger A. Shiner. "Theorizing Criminal Law Reform," dalam Criminal Law and Philosophy, 3.2, (Jun 2009), h. 167-186.

${ }^{33}$ Terry A Maroney, "Law and Emotion: A Proposed Taxonomy of an Emerging Field," dalam Law and Human Behavior, 30.2, April 2006, 119-42.

${ }^{34}$ Jason Walker, "The Rule of Law as an Emergent Order: How Stare Decisis Generates the Rule of Law from the Ground Up," (Disertasi: The University of Wisconsin, 2012).

${ }^{35}$ Michael J. Slinger, "Historical Development of the Librarian/Research Partnership in American Law Schools," dalam Journal of Law and Education, 39.3, Juli 2010, h. 387-410. 
sebagai user hukum itu, akan tetapi terletak pada penegakan hukum itu sendiri. Rekrutmen aparatur penegakan hukum harus dilakukan dengan cara memberikan akses kepada mereka yang memiliki kapasitas dan integrasi yang tinggi dalam menjalankan amanah penegak hukum. Sumber daya manusia yang mengisi tempat sebagai aparatur penegak hukum juga harus berasal dari sistem pendidikan yang baik karena mustahil mengharapkan output yang bagus bila tidak dilakukan sesuai aturan yang ada. Saat ini pejuang kebaikan menghadapi tantangan yang luar biasa dalam menegakkan nilai-nilai moral di masyarakat karena besarnya tekanan globalisasi yang mempengaruhi pola kehidupan masyarakat secara menyeluruh. Banyak dari golongan masyarakat yang terpengaruh sisi negatif dari tekanan globalisasi yang memaksakan melakukan penetrasi budaya ke dalam kehidupan masyarakat yang rentan.

Di sisi lain lemahnya posisi pihak umat Islam dewasa ini dalam organisasi-organisasi kemasyarakatan di berbagai sektor karena umat Islam tidak melakukan konsolidasi ke dalam. Konsolidasi tidak akan berhasil kalau masih menganggap saudaranya yang lain sebagai "mereka" bukan "kita". Karena ketika saudaranya yang seiman masih dianggap pihak luar, konsolidasi tidak akan mungkin berhasil. Dalam skala nasional saja dapat dilihat bagaimana perkara-perkara yang furu' tetap menjadi pertentangan dengan meninggalkan masalah-masalah yang esensi. Untuk menjelaskan posisi tawar pihak umat Islam harus mengkonsolidasi segala potensi kekuatan umat Islam di segala sisi, yaitu konsolidasi pemanfaatan sumber-sumber ekonomi, dan konsolidasi terhadap mental spiritual. Konsolidasi pemanfaatan sumber-sumber ekonomi ialah menggunakan segala upaya secara optimal untuk memakmurkan umat Islam. Bisa dilakukan dengan pemanfaatan sumber daya alam secara optimal maupun peningkatan sumber daya manusia sebagai katalisator kesejahteraan.

Bila Nabi Muhammad SAW. dalam konsolidasi pemanfaatan sumber-sumber ekonomi melalui modifikasi kekuatan ekonomi umat Islam terutama para saudagar yang besar seperti ‘Usmân bin 'Affân. Kemudian melalui mereka, Nabi Muhammad SAW mengatur strategi untuk mengimbangi kekuatan ekonomi Yahudi terutama oleh Bani Qainuqa, Quraiza, maupun Bani Huraifa yang menguasai ekonomi maupun politik kota Madinah saat itu. Dengan terjunnya para saudagar Islam yang memang terkenal keahliannya dalam berdagang lambat laun posisi ekonomi umat Islam makin meningkat sehingga secara otomatis tawar politik umat Islam pun tidak diperhitungkan. Di sinilah piawainya Nabi Muhammad SAW. berhasil mengatur strategi potensi umat Islam tersebut di sisi lain umat Islam yang kurang begitu pandai dalam berdagang didorong Nabi untuk menjadi juru dakwah, atau bagi mereka yang pandai baca tulis untuk mengajar mereka yang tidak pandai membaca maupun menulis, begitu juga bagi mereka yang memiliki keberanian 4 keterampilan bertempur didorong untuk menjadi prajurit-prajurit Islam yang tangguh. Dengan demikian, di segala sektor kehidupan waktu itu umat Islam menjalin kemitraan dengan pihak non-Muslim bargaining position umat Islam dalam menentukan.

Dalam kondisi sekarang ini bila umat Islam meniru apa yang dilakukan oleh Nabi 
Muhammad SAW., dengan memobilisasi kekuatan ekonomi umat Islam. Kalau umat Islam bisa memobilisasikan ekonomi umat Islam saat ini yang diibaratkan lahan tidur tentulah banyak hal yang diharapkan. Lihat saja hampir di setiap wilayah di muka bumi ini yang didiami kaum Muslim memiliki kandungan alam yang kaya. Akan tetapi, sangat disayangkan hampir semua hasil bumi yang ada di negara Muslim memiliki kandungan yang sangat berharga mulai dari minyak bumi, gas, batu posfat, dan nikel. Akan tetapi, sangat disayangkan hampir semua hasil bumi yang ada di negara Muslim dikelola oleh orang-orang asing yang notabene non-Muslim. Di sini nampak ketidakmampuan umat Islam dalam bersaing tersebut. Tetapi yang pasti, tentunya umat Islam tidak boleh membiarkan hal ini terus berlangsung, jadi harus bisa menjadi tuan di negeri sendiri, juga jadi budak di negeri sendiri. Salah satu caranya dengan membangun kepercayaan diri, "kalau orang lain bisa kenapa kita tidak". Sebagai konsolidasi terhadap mental spiritual yang dimaksud di sini ialah memodifikasi segala kemampuan spiritual yang kuat. Menurut kodratnya manusia memiliki dua kebutuhan, yaitu kebutuhan materi dan kebutuhan spiritual. Karena hakikat manusia itu pun gabungan antara dau bagian, yaitu jasmani dan ruhani. Bila di antara keduanya tidak lengkap, maka bukan dikatakan manusia.

\section{Primordialisme dan Social Identity}

Sebagaimana umumnya masyarakat metropolitan yang heterogen dampak dari perkembangan ekonomi yang terpusat di kota memiliki daya tarik yang tinggi bagi mereka yang ingin berjuang untuk meningkatkan taraf hidup. ${ }^{36}$ Istilah metropolitan menggambarkan betapa masifnya aktivitas yang ada di dalamnya mencakup hampir segala sektor tempat berkumpulnya segala elemen masyarakat. Dengan segala impian yang ada di dalam diri mereka untuk berjuang merahi obesi sehingga masing-masing pihak berkompetisi untuk melakukan hal yang terbaik. Ada banyak persoalan yang timbul dalam masyarakat metropolitan terutama berkaitan dengan kepribadian individu dalam melakukan hubungan inter-personal antara satu dengan yang lainnya. Biasanya masyarakat metropolitan yang berasal dari daerah tetap mempertahankan kebiasaan mereka sebisa mungkin demikian juga dengan bahasa daerah sebagai identitas yang tetap dipertahankan. Identitas kedaerahan terkadang muncul untuk memperkuat posisi masing-masing individu ketika berhadapan dengan komunitas yang lebih kompleks. Akan tetapi, tidak jarang dari masyarakat pendatang tidak ingin mengekspresikan bahasa daerah sebagai identitas diri mereka bila dirasakan tidak mendukung eksistensi diri.

Hubungan emosional satu suku atau satu daerah dianggap dapat menjadi alat bantu dapat bersaing dengan pihak lain. Bahasa daerah digunakan bukan hanya sebagai pertanda dalamnya kecintaan seseorang terhadap kampung halamannya juga semacam kode morse

\footnotetext{
${ }^{36}$ Roxanne Ezzet-Lofstrom, "Metropolitan Quality of Life: The Roles of Labor Markets, Land Markets and Amenities," (Disertasi: University of California, 2002).
} 
dalam hubungan sosial dengan pihak lainnya. Masyarakat di kota Medan pada umumnya menggunakan bahasa daerah mereka sebagai kode morse dalam pergaulan maupun aktivitas perdagangan mereka. Agak mengherankan juga banyak di antara masyarakat Tionghoa yang tidak menggunakan bahasa Hokkien ketika berada di luar negeri dengan sesama mereka akan tetapi menggunakan bahasa Indonesia. Hal ini ingin mempertegas identitas mereka berasal dari Indonesia seperti masyarakat pada umumnya. Karena sudah menjadi rahasia umum ekonomi Indonesia dipegang oleh sekelompok masyarakat Tionghoa sehingga penggunakan bahasa Indonesia sesama mereka di luar negeri untuk mempertegas status sosial mereka.

Bagi masyarakat Jawa kelahiran Sumatera Utara khususnya penggunaan bahasa daerah yang tetap dipertahankan bukan didasari oleh kepentingan bisnis. Lebih banyak karena kultur Jawa yang sangat menghargai budaya daerah mereka. Biasanya masyarakat Jawa di manapun berada akan terus mempertahankan bahasa daerahnya sebagai bagian dari identitas mereka. Bagi masyarakat Jawa pembudayaan bahasa daerah kepada anggota keluarga merupakan hal yang sangat penting untuk mempertahankan identitasnya. Karena identitas dari penamaan seseorang sangat sulit didapatkan kecuali bagi mereka yang berstatus ningrat dengan gelar kebangsawanan yang melekat dengan diri mereka. Sementara itu masyarakat Batak yang telah menetap di kota metropolitan agak jarang menggunakan bahasa daerah di rumah-rumah mereka. ${ }^{37}$ Karena penggunaan marga yang selalu melekat dengan nama mereka secara mudah mempertegas identitas asal daerah. Sangat jarang bagi masyarakat Batak untuk menghilangkan identitas marga yang bergandeng dengan nama mereka sebagai bagian dari identitas masyarakat mereka.

Hubungan antara satu individu dengan lainnya biasanya lebih intens di tempat-tempat yang secara alami terjadi seperti intensitas yang relatif sering berjumpa karena bertetangga, atau adanya satu kepentingan yang sama baik itu ekonomi maupun kegiatan sosial kemasyarakatan lainnya. Bagi masyarakat Muslim yang berlainan suku tampaknya kegiatan sosial keagamaan seperti wirid yasin dipandang sebagai sarana yang efektif untuk melakukan kontak sosial dengan lainnya. ${ }^{38} \mathrm{Hal}$ tersebut terjadi bagi mereka yang tidak lahir di daerah asal. Dengan kemajuan teknologi transportasi dan komunikasi, selain menyebabkan globalisasi yang menjadikan ruang menjadi sempit dan waktu menjadi pendek juga menyebabkan terjadinya deteritorialisasi. ${ }^{39}$

Ketika posisi politik umat Islam di Madinah menjadi pemain dominan maka Nabi

${ }^{37}$ Geoff Kushnick \& Daniel M. T. Fessler, "Karo Batak Cousin Mariage, Cosocialization, and the Westermarck Hypothesis," dalam Current Anthropology, Juni 2011, Vol. 52, Issue 3, h. 443448.

${ }^{38}$ Jean Bauberot, "Secularism and France Riligious Liberty: A sociological and Historical View," dalam Brighman Young University Law Review, 2003, h. 451.

${ }^{39}$ Abdul Syukur, "Islam, Etnitas, dan Politik Identitas," dalam MIQOT: Jurnal Ilmu-ilmu Keislaman, Vol. XXXV, No. 2 Juli-Desember 2011, h. 415. 
Muhammad memberikan instruksi bagi siapa saja yang mengurus tanah terlantar, maka tanah tersebut menjadi miliknya. Motivasi tersebut membuat tanah-tanah terlantar banyak dimanfaatkan oleh warga untuk kepentingan dalam skala yang lebih luas. Hal tersebut juga guna mencegah penguasaan lahan oleh segelintir elit yang membuat kehidupan bermasyarakat menjadi tidak sehat. Keadaan ini menimbulkan sikap permissive yang terjadi di dalam masyarakat secara umum, akan tetapi yang mengherankan rasa permissisve mayarakat dapat merusak kepercayaan terhadap sistem yang ada. ${ }^{40}$ Nuansa pragmatisme sering timbul akibat dari perilaku hedonisme dalam bersikap di masyarakat yang dianggap sebagai hal yang lumrah sehingga sangat membahayakan psikologi masyarakat. ${ }^{41}$ Perilaku menyimpang yang dianggap lumrah bisa saja berubah menjadi budaya yang sangat sulit untuk diberantas. Sudah menjadi kebiasaan bangsa Indonesia untuk memberikan sesuatu terhadap perbuatan pihak lain yang dianggap baik walaupun dalam tataran tugasnya sebagai pelayaan masyarakat. Untuk merubah paradigma yang demikian perlu kerja keras karena upeti dianggap sebagai bentuk balas jasa kepada seseorang yang telah berbuat baik. ${ }^{42}$ Sangat sulit untuk melakukan pemetaan wilayah imbalan balas jasa yang termasuk lingkup penyuapan atau tip seperi office boy yang melayani tamu ketika mau check in di sebuah hotel. Merupakan suatu hal biasa untuk memberikan tips bagi profesi tertentu yang dianggap lazim di dalam msayarakat karena petugas tersebut bukan sebagai penyelenggara negara. Gratifikasi merupakan perkara korupsi yang sangat sulit diberantas karena masih adanya persepsi yang muncul di dalam masyarakat hal itu merupakan kewajaran sebagai imbalan balas jasa. ${ }^{43}$

Pada umumnya setiap masyarakat yang masih memegang adat ketimuran memiliki model interaksi kekerabatan untuk membangun kekuatan kelompok dalam menghadapi segala betuk tantangan dari luar. Ineteraksi kekerabatan masyarakat Indonesia semakin jelas dilihat ketika berada di komunitas yang sangat heterogen terutama di kota-kota besar. Hal tersebut semakin memperjelas kode komunikasi di anatara mereka. Tingginya model interaksi kekerabatan sangat berpengaruh dengan situasi politik dan ekonomi.

Tanpa disadari stigma superior dan inferior akan terbentuk dari komposisi masyarakat yang tidak seimbang baik itu dari jumlah maupun dari aspek penguasaan sumber-sumber kekuatan ekonomi dan politik. Hal yang menjadi persoalan di dalam suatu masyarakat bila kelompok masyarakat yang dianggap mayoritas merasa terpinggirkan oleh situasi politik maupun ekonomi yang terjadi di lingkungannya. ${ }^{44}$ Bila kelompok masyarakat yang

${ }^{40} \mathrm{E} . \mathrm{B}$, "Capital Affairs: London and the Making of the Permissive Society," dalam Contemporary Review, Spring 2011, Vol. 293, Issue 1700, h. 122-123.

${ }^{41}$ Richard Shusterman, "Transactional Experiential Inquiry: From Pragmatism to Somaesthetics," dalam Contemporary Pragmatism, 2015, Vol. 12 Issue 1, h. 180-195.

${ }^{42}$ Andy Wood, "The Deep Roots of Albion's Fatal Tree: The Tudor State and the Monopoly of Violence," dalam History, Juli 2014, Vol. 99, Issue 336, h. 403-417.

${ }^{43}$ Paul Roberts, "Instant Gratification," dalam American Scholar, Autumn 2014, Vol. 83, Issue 4 , h. 18-31.

${ }^{44}$ Adam Schwarz, A Nation in Waiting: Indonesia Search For Stability (Washing: Allen dan Unwin, 1999), h. 330-331 
dominan secara populasi merasa dalam zona aman niscaya gesekan sosial nyaris tidak pernah terjadi hal tersebut disebabkan perasaan secured dari segala ancaman. Masyarakat yang pernah mengalami suatu peristiwa yang chaos tentunya akan lebih mudah terpancing untuk mengulang trauma masa lalu. Sebab itu perlu adanya langkah-langkah kongkrit untuk melakukan pencegahan peristiwa social diorder terjadi lagi khususnya di masyarakat Medan. Walaupun ada usaha untuk menghilangkan istilah pribumi dan non-pribumi akan tetapi hal tersebut masih saja melekat di dalam pergaulan sehari-hari di masyarakat. ${ }^{45} \mathrm{Hal}$ tersebut dapat disebabkan hubungan kemasyarakatan yang terbangun tidak begitu memberikan ruang terjalinnya komunikasi sosial yang dapat meningkatkan salaing pengertian antara satu yang lain.

Banyak aspek yang membuat kekakuan yang terjadi sehingga masih melekatnya istilah pribumi dan non-pribumi. Primordialisme masih begitu memegang peranan yang signifikan dalam mengatur hubungan antara masyarakat di Kota Medan khususnya. Kluster demografi penduduk Kota Medan umumnya termasuk di Medan di pusat-pusat kegiatan ekonomi biasanya dihuni oleh orang-orang beretnis tertentu, biasanya juga mereka berkelompok bertempat tinggal di komplek-komplek yang berdekatan dengan pusat kegiatan ekonomi. ${ }^{46}$ Bagi masyarakat menengah ke atas, alasan pengelompokan semacam kluster di beberapa wilayah yang seakan seperti lingkungan baru maupun kompleks perumahan yang memiliki petugas sekuriti didasarkan untuk alasan keamanan. Masyarakat di belahan bumi lainnya seperti di Eropa Barat juga mengalami ketegangan sosial disebabkan perubahan demografi yang terjadi akan imigrasi orang-orang yang memiliki latar belakang yang berbeda tetapi ketegangan sosial bukan akibat penguasaan ekonomi lebih baik pada kedatangan dari kultur yang berbeda.

Dalam membaca hubungan sosial yang terjadi di dalam suatu masyarakat selalu terkait dengan banyak faktor yang mempengaruhinya. Selalu saja ada kelompok masyarakat yang merasa termarginalkan oleh situasi yang ada, baik itu secara kultur, ekonommi, maupun politik. ${ }^{47}$ Hal tersebut disebabkan pengalaman sosial yang dirasakan oleh masing-masing individu yang tergabung di dalamnya sangat berbeda antara satu dengan yang lainnya. Persepsi terhadap konsep marginal berbeda anatara satu kelompok masyarakat dengan yang lainnya. Di Amerika misalnya kelompok minoritas yang merasa terpinggirkan karena kurang mendapat akses secara ekonomi dan politik. Kaum kulit hitam sering merasakan diskriminasi terhadap warna kulit masih kerap terjadi sehingga kasus penembakan seorang remaja kuulit hitam di negara bagian Georgia oleh seorang polisi memicu gelombang protes bagi masyarakat kulit hitam di seluruh negeri. Rasa ketidakadilan bagi kaum kulit hitam

${ }^{45}$ Jyrki Loima, "Secularism, Nationalism, and Minorities in Turkey," dalam Historian, Winter, 2014, Vol. 76, Issue 4, h. 750-765.

${ }^{46}$ Marilyn Porter \& Tita Marlita Hasan, "Exploring in Narative Research: Indonesian Study," dalam The Canadian Review of Sociology and Anthropology, 40.2 (May 2003), h. 153-170.

${ }^{47}$ Husserl, the Idea of Phenomenology, h. 35. 
bertambah terhadap sistem yang sudah ada setelah pihak pengadilan tingkat banding memutuskan bahwa petugas Polisi yang menembak seorang remaja kulit hitam yang dicurigai sebagai seorang kriminal merupakan tindakan yang bagi petugas keamanan tidak bisa disalahkan demi menjaga ketertiban masyarakat. Persepsi orang kulit hitam yang sering dikaitkan dengan tindakan kriminal didasarkan atas angka kejahatan yang kerap terjadi di kalangan ini. Tindakan polisi yang menembak remaja kulit hitam suatu malam di suatu lingkungan yang rawan aksi kriminal dapat dibenarkan. Dalam hal ini, sepertinya masyarakat minoritas tidak selalu dikaitkan dengan ketidak adilan secara ekonomi artinya dalam konteks Indonesia khususnya yang berada di Medan. ${ }^{48}$ Penguasaan terhadap sumber-sumber ekonomi yang begitu dominan oleh kelompok minoritas membuat hubungan sosial kemasyarakatan tidak begitu lancar. Karena ada semacam kecemburuan sosial yang begitu tinggi muncul bagi masyarakat yang merasa dimarginalkan oleh situasi seperti ini. Hubungan sosial yang kurang tulus yang terjadi di dalam masyarakat sebenarnya dapat diperbaiki dengan melakukan stimulus sosial. ${ }^{49}$ Stimulus sosial yang dimaksud ialah membuat semacam policy mengharuskan adanya interaksi sosial yang lebih intens dalam dimensi hubungan kemanusiaan yang lebih pure..$^{50}$ Selama ini tidak sedikit pencitraan semu yang terjadi antara kelompok-kelompok di masyarakat. Masyarakat Medan secara umum cenderung membentuk kluster-kluster sosial atas nama organisasi cenderung ekskulisivisme. Banyak muncul organisasi sosial kemasyarakatan yang eksklusif gambaran ada gejala konsolidasi sosial yang terjadi di masing-masing kelompok masyarakat. Ada semacam ketakutan yang muncul di dalam hati mereka tentang masa depan eksistensi yang mereka hadapi. Walaupun kebanyakan yang lahir adalah organisasi yang berbasis pada hubungan primordialisme akan tetapi ada juga organisasi yang berusaha melepaskan diri dari stigma primordialisme. Organisasi yang muncul di dalam kelompok masyarakat tidak selalu terkait dengan primordialisme tetap saja selfidentity yang ditampilkan memiliki pesan sosial tentang eksistensi mereka yang ingin diperhitungkan dalam pergaulan sosial secara umum. Adanya gejala pencitraan sosial melalui spanduk, poster, maupun baliho di jalan-jalan atau tempat-tempat strategis khususnya di Medan merupakan hal relatif baru dalam hubungan sosial. Ada semacam kebanggaan bagi individu yang menampilkan identitas mereka melalui media iklan di tempat-tempat umum sebagai bentuk ekspressi keberadaan mereka. ${ }^{51}$ Bagi kelompokkelompok masyarakat tertentu kegiatan ini sebagai usaha untuk mempertegas wilayah kekuasaan mereka. Artinya pesan yang ingin disampaikan kepada pihak saingannya bahwa mereka yang berkuasa di wilayah ini sehingga pihak lain harus menghormati mereka.

${ }^{48}$ Ritzer, Modern Sociological Theory, h. 235.

${ }^{49}$ Lisa Wood, "Targetting Ethnic Trade: Minorities by Lisa Wood: Minority Francisees Are Useful Role Models in Attracting Other Ethnic Groups to Set Up in Business-and Have the Experience of Doing So Themselves," dalam Financial Times (London: 26 June 2001).

${ }^{50}$ Jennel A. Harvey, "Community Social Capital and the Health Care Safety Net," (Disertasi: The University of Arizona, 2006).

${ }^{51}$ Heidi Prizmich, "Mass Media Manipulation and Gender: The Message Advertisements Are Sending Young Girls," (Disertasi: Gonzaga University, 2015). 
Selfidentity yang ditampilkan masing-masing individu di dalam masyarakat berbeda antara satu dengan yang lainnya. ${ }^{52}$ Self identity ini merupakan refleksi dari persepsi ingin diakui dan dikenal sehingga diharapkan orang lain mengakui tampilan identitas diri yang ditawarkan. Selfidentity merupakan suatu hal alami dalam kehidupan manusia karena setiap insan ingin diperlakukan dengan identitas yang diinginkannya. Penggunaan gelar akademik maun gelar-gelar sosial lainya merupakan bentuk lain dari self identity di dalam kehidupan ini. Masalahnya timbul ketika self identity yang diinginkan oleh sutu individu ataupun grup tidak direspon oleh kelompok individu atau kelompok masyarakat lainnya. ${ }^{53}$ Di sinilah timbul persaingan yang terkadang berujung clash kalau masing-masing pihak mengklaim sebagai sosok self identity yang sama.

Dalam memahami fenomena sosial yang ada sering sekali luput dari pengamatan adalah faktor-faktor tertentu di luar masalah utama dalam hubungan sosial. Setiap individu yang tergabung dalam suatu kelompok masyarakat disebabkan ingin survive sehingga membentuk aliansi yang diharapkan dapat meningkatkan posisi tawar mereka dengan kelompok masyarakat lainnya. Rendahnya posisi tawar kelompok masyarakat tertentu disebabkan banyak faktor termasuk ekonomi, politik, maupun seberapa penting kelompoknya diakui di dalam masyarakat. Ketika suatu kelompok masyarakat secara ekonomi dan politik marginal, maka langkah yang dilakukannya dengan melakukan usaha seberapa pentingnya mereka di dalam masyarakat. ${ }^{54}$ Artinya, ada dalam fase-fase tertentu suatu kelompok masyarakat ingin juga diakui pentingnya keberadaan mereka yaitu dengan menanamkan pesan moral utama di dalam masyarakat. Beberapa kelompok di dalam masyarakat misalnya banyak yang memasang baliho bahwasanya mereka ikut mendukung memberantas narkoba sebagai musuh bangsa. Walaupun secara valid tidak ditemukan usaha apa saja yang telah mereka lakukan dalam mendukung usaha pemberantasan narkoba. Akan tetapi, hal itu dilakukan sebagai usaha untuk mengangkat citra di dalam msayarakat betapa kelompok ini memiliki peran yang penting mengkaitkan dengan isu-isu seksi yang menjadi topik utama di dalam masyarakat.

Kelompok primordialisme masyarakat Medan belum begitu memiliki peran yang penting dalam kegiatan ekonomi maupun politik di dalam masyarakat. ${ }^{55}$ Pada dasarnya manusia secara naluri selalu ingin hidup berkelompok secara homogen demi untuk mempertahankan diri segala potensi ancaman terhadap diri mereka. ${ }^{56} \mathrm{Hal}$ ini dapat dilihat dari sejarah

${ }^{52}$ Jennifer Wen-Shya Lee, "The Effect of Ethnic Identity and Bilingual Confidence on Chinese Youth's Self," dalam Alberta Journal of Educational Research, 54.1 (Spring 2008), h. 83-96.

${ }^{53}$ Andrea V Breen, "The Construction of Self-Identity and Positive Behavioural Change in Pregnant and Parenting Young Women," (Disertasi: University of Toronto, 2010).

${ }^{54}$ Koentjaraningrat, Pengantar Ilmu Antropologi (Jakarta: Rineka Cipta, 1990), h. 165.

${ }^{55}$ Kate Meagher, "Cultural Primordialism and The Post-Structuralist Imaginaire: Plus Change," dalam Africa (Pre-2011), 76. 4, (2006).

${ }^{56}$ R.J. Turner. Marino, "Social Support and Social Structure: a Descriptive Epidemiology F.," dalam Journal of Health and Social Behavior, 35.3 (September 1994), h. 193-212. 
manusia semenjak dahulu ketika mereka membentuk kelompok masyarakat yang relatif satu keturunan sehingga lebih mudah untuk melakukan konsolidasi yang diperlukan dalam segala kepentingan. Kesamaan suku atau bangsa dapat membuat ikatan anggota kelompok masyarakat saling membutuhkan satu dengan lainnya serta adanya perasaan persaudaraan yang tinggi karena berasal dari klan suku yang sama. Sejarah membuktikan banyak sekali contoh keberhasilan suatu suku bangsa yang menjelma menjadi kekuatan besar dalam bentuk kerajaan. Seiring dengan perubahan zaman tampaknya konsentrasi kesukuan tidak lagi menjamin terwujudnya kesamaan pandangan membentuk identitas di dalam suatu kelompok. Kepentingan yang berbeda terkadang menyingkirkan ikatan primordialisme yang selama ini sangat ampuh dalam merajut ikatan emosional di dalam masyarakat. Ancaman terhadap nilai kesakralan ikatan kesukuan kadang kala datang dari persaudaran yang ditimbulkan dari agama. Ikatan satu keyakinan dalam bentuk keagamaan sering sekali mengalahkan ikatan primordialisme yang selama ini ampuh untuk menjaga hubungan antara anggota masyarakat. Hubungan satu keyakinan agama membentuk suatu komunikasi internal yang menciptakan aliansi baru dalam komunitas. Kluster masyarakat mengalami perubahan dari tahun ketahun. Hal tersebut didasari dari perubahan peta kelompok masyarakat yang mendiami di suatu tempat seiring dengan kemampuan kelompok masyarakat tersebut dalam merespons perubahan masa. Tesis manusia yang selalu ingin hidup secara homogen karena ingin mempertahankan diri dari segala ancaman harus disesuaikan dengan bentuk tantangannya. Dewasa ini di kota-kota besar konsentrasi kelompok masyarakat tidak lagi didasarkan oleh dasar kesukuan lagi akibat dari tekanan ekonomi maupun politik yang dialami oleh masyarakat tersebut. ${ }^{57}$

Kecenderungan masyarakat global melakukan polarisasi dampak dari perkembangan demografi, sosial, ekonomi, maupun politik merupakan suatu keniscayaan. Di tingkat global banyak sekali organisasi-organisasi kawasan yang berdiri wujud dari penguatan solidaritas kawasan untuk membentuk suatu aliansi. Fakta tidak ada satupun negara di dunia ini yang bisa berdiri sendiri membuat negara-negara kawasan menyadari betapa aliansi kawasan dapat meningkatkan mobilitas masyarakat di dalamnya. Bahkan di Eropa sendiri berdiri aliansi terpadu yang menghilangkan sekat-sekat wilayah kovensional demikian juga dari segi ekonomi selain menciptakan mata uang tunggal juga membentuk economy market bersama. ${ }^{58}$ Aliansi uni Eropa ternyata dapat meningkatkan posisi tawar kawasan tersebut menjadi lebih tinggi di pentas internasional bahkan mata uang Euro menjadi salah satu mata uang terpenting (world currency reserve). Sebenarnya masyarakat asean lebih dahulu menyadari betapa pentingnya persatuan di antara negara-negara sekawasan dengan terbentuknya

${ }^{57}$ Lijun Song, "Social Capital and Psychological Distress," dalam Journal of Health and Social Behavior, 52.4 (Dec 2011), h. 478-492.

${ }^{58}$ Manuel Gomez, "Explaining the Euro Exchange Rate: The Role of Policy Uncertainty, Asymmetric Information and Hedging Opportunities," (Disertasi: Arizona State University, 2003). 
organisasi ini tanggal 8 agustus $1967 .{ }^{59}$ Akan tetapi semangat kebersamaan masih diimplementasi dalam tataran kesamaan pandangan dalam urusan tidak intervensi urusan politik dalam negeri juga kerja sama budaya antara anggotanya. Baru satu dekade yang lalu dapat dilihat ada semangat baru untuk meningkatkan kerja sama sampai pada level yang lebih aplikatif yaitu di bidang ekonomi. Walaupun bentuk kerja sama ekonomi belum sampai pada pembentukan mata uang tunggal seperti di Eropa. Akan tetapi, langkah pembentukan pasar bebas ASEAN ini merupakan langkah maju yang diharapkan akan menciptakan pasar tunggal asean. Hal ini penting untuk meningkatkan daya saing kawasan ini dalam menghadapi kekuatan ekonomi global seperti Amerika, China, India, maupun Uni Eropa tentunya.

Self identity yang ditampilkan masing-masing individu di dalam masyarakat berbeda antara satu dengan yang lainnya. ${ }^{60}$ Self identity ini merupakan refleksi dari persepsi ingin diakui dan dikenal sehingga diharapkan orang lain mengakui tampilan identitas diri yang ditawarkan. Selfidentity merupakan suatu hal alami dalam kehidupan manusia karena setiap insan ingin diperlakukan dengan identitas yang diinginkannya. Penggunaan gelar akademik maun gelar-gelar sosial lainya merupakan bentuk lain dari self identity di dalam kehidupan ini. Masalahnya timbul ketika self identity yang diinginkan oleh sutu individu ataupun grup tidak direspon oleh kelompok individu atau kelompok masyarakat lainnya. ${ }^{61}$ Di sinilah timbul persaingan yang terkadang berujung clash kalau masing-masing pihak meng-claim sebagai sosok selfidentity yang sama. Dalam memahami fenomena sosial yang ada sering sekali luput dari pengamatan adalah faktor-faktor tertentu di luar masalah utama dalam hubungan sosial. Setiap individu yang tergabung dalam suatu kelompok masyarakat disebabkan ingin survive sehingga membentuk aliansi yang diharapkan dapat meningkatkan posisi tawar mereka dengan kelompok masyarakat lainnya. Rendahnya posisi tawar kelompok masyarakat tertentu disebabkan banyak faktor termasuk ekonomi, politik, maupun seberapa penting kelompoknya diakui di dalam masyarakat. Ketika suatu kelompok masyarakat secara ekonomi dan politik marginal maka langkah yang dilakukannya dengan melakukan usaha seberapa pentingnya mereka di dalam masyarakat. ${ }^{62}$ Artinya ada dalam fase-fase tertentu suatu kelompok masyarakat ingin juga diakui pentingnya keberadaan mereka yaitu dengan mendompleng pesan moral utama di dalam masyarakat. Beberapa kelompok di dalam masyarakat misalnya banyak yang memasang baliho bahwasanya mereka ikut mendukung memberantas narkoba sebagai musuh bangsa. Walaupun secara valid tidak ditemukan usaha apa saja yang telah mereka lakukan dalam mendukung usaha

59"Thailand/ASEAN: First Meeting of ASEAN Political-Security Community Council Asia News Monitor," (Bangkok, 14 April 2009).

${ }^{60}$ Jennifer Wen-Shya Lee, "The Effect of Ethnic Identity and Bilingual Confidence on Chinese Youth's Self," dalam Alberta Journal of Educational Research, 54.1 (Spring 2008), h. 83-96.

${ }^{61}$ Andrea V. Breen, "The Construction of Self-Identity and Positive Behavioural Change in Pregnant and Parenting Young Women," (Disertasi: University of Toronto, 2010).

${ }^{62}$ Koentjaraningrat, Pengantar Ilmu Antroplogi, 165. 
pemberantasan narkoba. Akan tetapi, hal itu dilakukan sebagai usaha untuk mengangkat citra di dalam msayarakat betapa kelompok ini memiliki peran yang penting mengkaitkan dengan isu-isu seksi yang menjadi topik utama di dalam masyarakat.

Kelompok primordialisme masyarakat Medan belum begitu memiliki peran yang begitu penting dalam kegiatan ekonomi maupun politik di dalam masyarakat. ${ }^{63}$ Pada dasarnya manusia secara naluri selalu ingin hidup berkelompok secara homogen demi untuk mempertahankan diri segala potensi ancaman terhadap diri mereka. ${ }^{64} \mathrm{Hal}$ ini dapat dilihat dari sejarah manusia semenjak dahulu ketika mereka membentuk kelompok masyarakat yang relatif satu keturunan sehingga lebih mudah untuk melakukan konsolidasi yang diperlukan dalam segala kepentingan. Kesamaan suku atau bangsa dapat membuat ikatan anggota kelompok masyarakat saling membutuhkan satu dengan lainnya serta adanya perasaan persaudaraan yang tinggi karena berasal dari klan suku yang sama. Sejarah membuktikan banyak sekali contoh keberhasilan suatu suku bangsa yang menjelma menjadi kekuatan besar dalam bentuk kerajaan. Seiring dengan perubahan zaman tampaknya konsentrasi kesukuan tidak lagi menjamin terwujudnya kesamaan pandangan membentuk identitas di dalam suatu kelompok. Kepentingan yang berbeda terkadang menyingkirkan ikatan primordialisme yang selama ini sangat ampuh dalam merajut ikatan emosional di dalam masyarakat. Ancaman terhadap nilai kesakralan ikatan kesukuan kadang kala datang dari persaudaran yang ditimbulkan dari agama. Ikatan satu keyakinan dalam bentuk keagamaan sering sekali mengalahkan ikatan primordialisme yang selama ini ampuh untuk menjaga hubungan antara anggota masyarakat. Hubungan satu keyakinan agama membentuk suatu komunikasi internal yang menciptakan aliansi baru dalam komunitas. Kluster masyarakat mengalami perubahan dari tahun ketahun, hal tersebut didasari dari perubahan peta kelompok masyarakat yang mendiami di suatu tempat seiring dengan kemampuan kelompok masyarakat tersebut dalam merespon perubahan masa. Tesis manusia yang selalu ingin hidup secara homogen karena ingin mempertahankan diri dari segala ancaman harus disesuikan dengan bentuk tantangannya. Dewasa ini di kota-kota besar konsentrasi kelompok masyarakat tidak lagi didasarkan oleh dasar kesukuan lagi akibat dari tekanan ekonomi maupun politik yang dialami oleh masyarakat tersebut. ${ }^{65}$

Seorang individu yang tinggal di Medan akan memiliki variabel kehidupan yang mempengaruhi identitas diri yang melekat padanya tergantung asal kampung halamannya, suku, agama, maupun ekonomi, serta kehidupan di rumah tangga. Agak lebih sulit melakukan kluster pola identitas sosial yang terjadi pada masyarakat yang memiliki latar belakang variable kehidupan yang berbeda dengan kelompok mayarakat yang relatif berasal dari pola variable yang sama. Akan lebih mudah mengatur serta mengarahkan suatu masyarakat yang relatif memiliki pola variable yang sama dalam artian kehidupan sosial yang memiliki latar belakang

\footnotetext{
${ }^{63}$ Kate Meagher, "Cultural Primordialism."

${ }^{64}$ Marino, "Social Support and Social Structure," h. 193-212.

${ }^{65}$ Song, "Social Capital and Psychological," h. 478-492.
} 
sosial maupun keagamaan yang sama (homogen). Itu sebabnya kenapa di wilayah-wilayah tertentu yang cenderung homogen tingkat keteraturan masyarakatnya baik dari segi berlalu lintas maupun kebersihan cenderung lebih baik di banding kota-kota yang metropolitan seperti Jakarta maupun Medan. Karena kedua kota di atas gambaran dari masyarakat yang sangat heterogen bahkan penduduk pribuminya sudah tersingkir sebagai pemain utama di masyarakat. ${ }^{66}$ Sebab itu, kesemrautan maupun kebersihan merupakan salah satu tolak ukur dalam memilihat betapa teratur suatu masyarakat akan lebih sulit didapatkan di masyarakat yang tingkat heteroginitasnya tinggi yang menyebab-kan tersingkirkan masyarakat pribumi (tuan rumah) di panggung sosial. Surabaya merupakan kota metropolitan akan tetapi tingkat hetrogonitas masyarakatnya tidak begitu tinggi bahkan pribumi tetap bisa eksis di kehiupan sosial sehingga kota ini agak lebih mudah diatur dalam hal kebersihan dan lainnya. Karena orang pribumi tetap memilki peran yang penting dalam kehidupan sosial sehingga mereka yang berasal dari luar sebagai pendatang memiliki patron dalam bermasyarakat di daerah tersebut. ${ }^{67}$ Lain halnya di daerah Medan, kota metropolitan ini sepertinya masih sangat gamang dalam mengekpresikan identitas sosial yang dimilikinya karena masih belum jelasnya patron nilai-nilai identitas sosial yang hendak diusung. Hal tersebut disebabkan latar belakang nilai-nilai lokal yang tidak jelas disebabkan daerah ini merupakan ekses dari pengembangan Kota Medan. Dalam perjalanannya banyak orangorang yang melakukan perpindahan sekitar 50 tahun lalu yang akhirnya membentuk komunitas tersendiri. Dalam perkembangannya, Medan mengalami berbagai perubahan pola kluster tempat tinggal akibat dari kepindahan masyarakat Muslim yang kemudian digantikan oleh kelompok masyarakat etnis Tionghoa. Masyarakat Tionghoa di Medan tidak seperti di kota-kota lainnya di Indonesia yang menggunakan bahasa lokal dalam kehidupan sehari-hari. Akan tetapi, masyarakat Tionghoa di Medan mereka selalu saja menggunakan bahasa Hokkien yang berasal dari Tiongkok dalam kegiatan sosial sesama mereka. ${ }^{68}$ Hal tersebut menimbulkan persepsi tersendiri di kalangan masyarakat lokal terhadap tampilan identitas sosial masyarakat mereka.Tidak adanya etnis yang dominan di Sumatera Utara menjadikan daerah ini relatif lebih rentan terhadap clash social. Demikian juga yang terjadi di kalangan masyarakat lainnya yang berasal dari latar belakang suku lainnya.

\section{Konektivitas Subjek Penelitian dan Variabel-Variabel}

Berdasarkan data di Medan sebagai ibukota Sumatera Utara lebih dari 2 juta orang merupakan angka cukup besar. Medan merupakan salah satu kota yang padat di Indonesia yang didiami berbagai etnis, agama, maupun suku bangsa. Di sisi lain bagi masyarakat

${ }^{66}$ Gavrilets, "Philosophical Transactions," dalam Biological Sciences, Desember 2015, Vol. 370.

${ }^{67}$ Stanton Wortham \& Catherine Rhodes, "Life as a Chord: Heterogeneous Resources in the Social Identification of One Migrant Girl," dalam Applied Linguistics, Desember 2013, Vol. 34 , Issue 5, h. 536-553.

${ }^{68}$ Hoon, "Multicultural Citizenship Education in Indonesia," 490-510. 
Medan tampaknya setiap walikota tidak memiliki konsep yang jelas dalam menentukan identitas sosial yang ingin ditampilkan di dalam masyarakat. Realitas etnis Melayu yang dianggap sebagai kelompok masyarakat tuan rumah dengan peninggalan beberapa bangunan kerajaan Melayu seperti Istana Maimun dan Masjid Raya al-Mashun. Masyarakat Melayu yang dari segi jumlah dan penguasaan ekonomi yang sangat minim di Kota Medan seharusnya mendapatkan hak yang lebih dijadikan patron sosial bagi kelompok-kelompok masyarakat lainnya di Kota Medan. Akan tetapi, selama bertahun-tahun lamanya identitas kota Medan identik dengan suku Batak dan sekarang sudah mulai bergeser ke etnis Tionghoa. Selama ini Kota Medan selalu diidentikkan dengan suku Batak membuat semakin rancu semangat identitas sosial kota ini selama berpuluh-puluh tahun lamanya. Karakter suku Melayu tidak seperti suku Betawi di Jakarta maupun saat ini telah menjadi kelompok minoritas dan relatif terpinggirkan, akan tetapi identitas sosial kota Jakarta tetap menjadikan adat budaya Betawi sebagai patron sosial yang harus diikuti maupun dipatuhi oleh pemerintah maupun masyarakat pendatang di sana. ${ }^{69}$ Sementara ini suku Melayu yang seyogyanya sebagai tuan rumah di kota Medan selama ini kurang begitu reaktif bahkan cenderung mengalah dengan tekanan kaum pendatang seakan dipinggirkan dalam pentas sosial, ekonomi dan politik. Hal tersebut disebabkan kurang terkordinasi dengan baik usaha dalam memobilitas kekuatan sumber daya yang ada dalam komunitas tersebut. Ada kesan mereka kalah bersaing dengan kaum pendatang lainnya sehingga menyingkir di daerah-daerah pinggiran pantai. Patron sosial sebagai tuan rumah di tanah Melayu selama ini perlu adanya keberpihakan dari pemerintah khususnya terhadap mempertahankan identitas utama dalam kebudayaan melayu di kota Medan. Usaha ini diharapkan dapat menjadi penyeimbang dari penetrasi budaya dari kelompok-kelompok masyarakat yang tinggal di kota Medan.

Formalisasi hukum penting demi menjamin keteraturan dalam menetapkan hukum suatu perkara sehigga dapat mengindari pertentangan penafsiran masing-masing argumen yang ada. ${ }^{70}$ Makin tingginya pendidikan suatu bangsa bukan berarti ketaatan hukum semakin tinggi tidak jarang yang muncul adalah kepandaian dalam mencari celah hukum yang bisa dilanggar. Munculnya berbagai profesi hukum baik itu hakim, jaksa, maupun pengacara menunjukkan lafal hukum yang terterah di dalam pasal-pasal hukum dapat didekati dengan pendekatan yang berbeda. ${ }^{71}$ Walaupun semangat untuk menciptakan atau merumuskan suatu rancangan hukum dibuat dengan sedetail mungkin agar tidak muncul penafsiran ganda. Peristiwa hukum yang lazim terjadi di dalam masyarakat masih saja menimbulkan gejolak yang ada di dalam masyarakat, terutama yang menyangkut dengan perkara-perkara

${ }^{69}$ Paula Gerstenblatt \& Dorie J. Gilbert, "Framing Service Learning in Social Work: An Interdisciplinary Elective Course Embedded within a University-Community Partnership," dalam Social Work Education. Desember 2014, Vol. 33, Issue 8, h. 1037-1053.

${ }^{70}$ Harry W More, "Teams-Groups-Task Forces in Law Enforcement: The Wave of the Future," Springfield: Charles C. Thomas, 2012.

${ }^{71}$ Alyson Forbes, "Public Safety and Law Enforcement," dalam Field Guides to Finding a New Career. New York, NY: 2010. 
sensitif. Kenyataannya latar belakang maupun motivasi suatu peristiwa hukum bisa membuat putusan hukum yang berbeda sehingga dalam tataran tertentu terkadang hukum tidak bisa menjangkau hakikat keadilan yang di cari.

Instrumen hukum konvensional sangat terkait dengan prinsip-prinsip aliran positivisme di dalam hukum akan lebih mudah dikelabui bila hanya didasarkan dengan lafal teks. Berbeda dengan semangat yang berlaku di dalam hukum Islam yang mendorong prinsip keadilan lebih diutamakan di dalam penerapan hukum yang dalam penerapannya lebih mementingkan integritas individu yang dipercaya. Betapa banyak lafaz teks nash yang mengindikasikan bahwasanya seseorang yang telah melanggar sumpahnya tidak boleh diterima testimoni hukumnya untuk selamanya. Integritas individu sangat dijunjung tinggi sehingga ketsiqqahan merupakan hal yang sangat penting sebelum melakukan verifikasi terhadap perbuatan maupun perkataannya di depan hukum. ${ }^{72}$ Bila hukum konvensional masih memberikan toleransi kepada penegak hukum yang nyata-nyata melanggar kode etik yang disepakati dalam hal menanamkan trust kepada masyarakat. Trust akan sendirinya muncul bila integrasi dari pribadi-pribadi penegak hukum dapat meyakinkan publik terhdap komitmennya dalam penegakan hukum. Bagaimana mungkin masyarakat mempercayai sosok penegak hukum bila dalam kesehariannya tidak menunjukkan kejujuran dalam bertugas seperti rekrutmen, sumber kekayaan maupun perilaku. ${ }^{73}$

Masalah hukum yang kerap terjadi di dalam masyarakat muncul akibat adanya putusan hukum yang dilakukan oleh aparatur penegak hukum yang melanggar rasa keadilan masyarakat. Lembaga pengawas suatu institusi refleksi betapa integritas penegakan hukum harus tetap diawasi. Sementara itu, masyarakat umum hanya mengharapkan mitos keadilan masih dalam angan-angan, karena hal itu sepertinya sulit untuk dicapai. Kasus penguasaan aset publik yang terjadi oleh segelintir golongan elit di masyarakat tidak akan bisa terjadi bila lebih menagkomodir kepentingan masyarakat secara umum. ${ }^{74}$ Dalam masyarakat Indonesia yang mayoritas penduduknya adalah Muslim, ternyata prinsip liberal kapitalis masih sangat dominan sehingga praktik untuk lebih memperdayakan masyarakat masih sangat kurang.

\section{Penutup}

Identitas sosial pada suatu masyarakat muncul dilatarbelakangi oleh beberapa faktor yang mempengaruhinya. Faktor alam, kondisi sosial, maupun hal yang menyangkut dengan SARA dapat membentuk identitas sosial yang terbentuk. Pada masyarakat homogen identitas

${ }^{72}$ Warren Eschenbach, "Integrity, Commitment, and a Coherent Self," dalam Journal of Value Inquiry. September 2012, Vol. 46, Issue 3, h. 369-378.

${ }^{73}$ Ovan Babiæ, "Pacifism and Moral Integrity," dalam Philosophia, Desember 2013, Vol. 41, Issue 4, h. 1007-1016.

${ }^{74}$ Seok Eun Kim, "Physical Workplace as a Strategic Asset for Improving Performance in Public Organizations," dalam Administration \& Society. Juli 2014, Vol. 46 Issue 5, h. 496-518. 
sosial yang terbentuk biasanya dimotori oleh tokoh-tokoh yang memiliki reputasi sebagai pihak yang tetap mempertahankan tradisi yang telah berlangsung sejak lama. Awalnya peran tokoh masyarakat sangat menonjol sebagai figur yang dianggap paling otoritatif dalam memepertahankan nilai-nilai budaya sebagai wujud dari identitas sosial pada masyarakat itu. seiring dengan perkembangan zaman pengaruh kekuatan ekonomi juga merambah di ranah simbol-simbol identitas sosial sehingga pemodal yang kuat di dalam masyarakat juga mencoba merebut pengaruh dengan menggandeng mereka yang dianggap sebagai figur utama yang mempertahankan identitas kelompok.

Hubungan masyarakat di kota metropolitan pada umumnya hampir di setiap tempat masing-masing mengalami suatu tekanan dari luar sehingga merasa eksistensinya terancam dengan pihak lain. Karena itu, masing-masing kelompok masyarakat berusaha membentuk suatu aliansi persaudaraan atau kedaerahan yang dimaksudkan untuk memperkuat mereka menghadapi tantangan tersebut. Tampaknya aliansi kemasyarakatan yang terbentuk merupakan cerminan dari naluri manusia untuk tetap bertahan hidup. Salah satu instrumen yang digunakan oleh masyarakat perkotaan dengan mengikatkan diri interpersonal dengan faktor kedaerahan.

Masyarakat Melayu yang dari segi jumlah dan penguasaan ekonomi yang sangat minim di Kota Medan seharusnya mendapatkan hak yang lebih dijadikan patron sosial bagi kelompok-kelompok masyarakat lainnya di Kota Medan. Akan tetapi, selama bertahun-tahun lamanya identitas kota Medan identik dengan suku Batak dan sekarang sudah mulai bergeser ke etnis Tionghoa. Selama ini Kota Medan selalu diidentikkan dengan suku Batak yang membuat semakin rancu semangat identitas sosial kota ini selama berpuluh-puluh tahun lamanya. Karakter suku Melayu tidak seperti suku Betawi di Jakarta maupun saat ini telah menjadi kelompok minoritas dan relatif terpinggirkan, akan tetapi identitas sosial kota Jakarta tetap menjadikan adat budaya Betawi sebagai patron sosial yang harus diikuti maupun dipatuhi oleh pemerintah maupun masyarakat pendatang di sana. Sementara ini suku Melayu yang seyogyanya sebagai tuan rumah di kota Medan selama ini kurang begitu reaktif bahkan cenderung mengalah dengan tekanan kaum pendatang.

\section{Pustaka Acuan}

A. Maroney, Terry. "Law and Emotion: A Proposed Taxonomy of an Emerging Field," dalam Law and Human Behavior, 30.2, April 2006.

Ahmad, Saeed. "Role of Socioeconomic Status and Political Participation in Construction of Apathy Among Youth," dalam Journal of Human Behavior in the Social Environment, November-Desember 2015, Vol. 25, Issue 8.

B, E. "Capital Affairs: London and the Making of the Permissive Society," dalam Contemporary Review, Spring 2011, Vol. 293, Issue 1700.

Babiæ, Ovan. "Pacifism and Moral Integrity," dalam Philosophia, Desember 2013, Vol. 41, Issue 4. 
Bauberot, Jean. "Secularism and France Riligious Liberty: A sociological and Historical View," dalam Brighman Young University Law Review, 2003.

Breen, Andrea V. "The Construction of Self-Identity and Positive Behavioural Change in Pregnant and Parenting Young Women.” Disertasi: University of Toronto, 2010.

Breen, Andrea V. "The Construction of Self-Identity and Positive Behavioural Change in Pregnant and Parenting Young Women." Disertasi: University of Toronto, 2010.

Deb, Mrinmay. "Assortment Planning of Vertically Differentiated Products Under Consumer Choice," dalam The Pennsylvania State University, 2013.

Doglas Taruvinga, Feremenga. "Local Urban Development Stakeholders in Globalizing Context: Civil Society, Urban Governance and Urban Poverty in Harare, Zimbabwe." Disertasi, University of California.

Du, Hang. "American College Students Studying Abroad in China: Language, Identity, and Self-Presentation," dalam Foreign Language Annals, June 2015, Vol. 48 Issue 2.

Eschenbach, Warren. "Integrity, Commitment, and a Coherent Self," dalam Journal of Value Inquiry. September 2012, Vol. 46, Issue 3.

Fadl, Khaled Abou El. The Place of Tolerance in Islam. Boston: Beacon, 2002.

Forbes, Alyson. "Public Safety and Law Enforcement," dalam Field Guides to Finding a New Career. New York, NY: 2010.

G. Kippenberg, Hans. "Phoenix from the Ashes: Religious Communities Arising from Globalization," dalam Journal of Religion in Europe, Vol. 6 Issue 2, 2013.

Gavrilets. "Philosophical Transactions," dalam Biological Sciences, Desember 2015, Vol. 370.

Gerstenblatt, Paula \& Dorie J. Gilbert, "Framing Service Learning in Social Work: An Interdisciplinary Elective Course Embedded within a University-Community Partnership," dalam Social Work Education, Desember 2014, Vol. 33, Issue 8.

Gerstenblatt, Paula \& Dorie J. Gilbert, "Framing Service Learning in Social Work: An Interdisciplinary Elective Course Embedded within a University-Community Partnership," dalam Social Work Education. Desember 2014, Vol. 33, Issue 8.

Gomez, Manuel. "Explaining the Euro Exchange Rate: The Role of Policy Uncertainty, Asymmetric Information and Hedging Opportunities." Disertasi: Arizona State University, 2003.

Harris, Max. "The Rule of Law in Private Law: A New Animating Ideal for Employment Law?," dalam New Zealand Journal of Employment Relations, 37.1, 2012.

Harvey, Jennel A. "Community Social Capital and the Health Care Safety Net." Disertasi: The University of Arizona, 2006.

Hasmiati, Hamra, et al., "Designing an English Course Book for High School Students Based on 2013 Curriculum," dalam Journal of Language Teaching \& Research. Vol. 6 Issue 6, 2015.

Hoon, Chang-Yau. "Multicultural Citizenship Education in Indonesia: The Case of a Chinese Christian School," dalam Journal of Southeast Asian Studies, Oktober 2013, Vol. 44, Issue 3. 
MIQOT Vol. XLI No. 2 Juli-Desember 2017

Husserl, Edmund. The Idea of Phenomenology, terj. Lee Hardy. Dordrecht: Kluwer, 1999.

J. Crosson, Frederick. "Fanatics, Politics and Religion Philosophy Today," 47.4, Winter 2003. Jarror, Husni Adham. Pergilah ke Jalan Islam: Sebuah Paket Metode Gerakan Islam Masa Kini, terj. Abu Fahmi. Jakarta: Gema Insani Press, 1989.

Keddie, Amanda. "Political Justice, Schooling and Issues of Group Identity," dalam Educational Philosophy \& Theory. Maret 2014, Vol. 46 Issue 3.

Kim, Seok Eun. "Physical Workplace as a Strategic Asset for Improving Performance in Public Organizations," dalam Administration \& Society. Juli 2014, Vol. 46 Issue 5.

Koentjaraningrat. Pengantar Ilmu Antropologi. Jakarta: Rineka Cipta, 1990.

Kushnick, Geoff \& Daniel M. T. Fessler. "Karo Batak Cousin Mariage, Cosocialization, and the Westermarck Hypothesis," dalam Current Anthropology, Juni 2011, Vol. 52, Issue 3.

Lee, Jennifer Wen-Shya. "The Effect of Ethnic Identity and Bilingual Confidence on Chinese Youth's Self," dalam Alberta Journal of Educational Research, 54.1., Spring 2008.

Lee, Jennifer Wen-Shya. "The Effect of Ethnic Identity and Bilingual Confidence on Chinese Youth's Self," dalam Alberta Journal of Educational Research, 54.1. Spring 2008.

Lofstrom, Roxanne Ezzet. "Metropolitan Quality of Life: The Roles of Labor Markets, Land Markets and Amenities." Disertasi: University of California, 2002.

Loima, Jyrki. "Secularism, Nationalism, and Minorities in Turkey," dalam Historian, Winter, 2014, Vol. 76, Issue 4.

Lovell, Ben. "We are a Tight Community': Social Groupsand Social Identity in Medical Undergraduates," dalam Medical Education. Oktober 2015, Vol. 49, Issue 10.

Marino, R.J. Turner. "Social Support and Social Structure: a Descriptive Epidemiology F.," dalam Journal of Health and Social Behavior, 35.3, September 1994.

Meagher, Kate. "Cultural Primordialism and The Post-Structuralist Imaginaire: Plus Change," dalam Africa (Pre-2011), 76. 4, 2006.

Ogurlu, Üzeyir. "Relationship between Cognitive Intelligence, Emotional Intelligence and Humor Styles," dalam International Online Journal of Educational Sciences, Juni 2015, Vol. 7 Issue 2.

Piore, Michael J. \& Paul Osterman. Economy in Society: Essays in Honor of Michael J. Piore. Cambridge, Mass.: The MIT Press, 2013.

Porter, Marilyn \& Tita Marlita Hasan. "Exploring in Narative Research: Indonesian Study," dalam The Canadian Review of Sociology and Anthropology, 40.2, May 2003.

Porter, Marilyn. "Tita Marlita Hasan," dalam The Canadian Review of Sociology and Anthropology, 40.2, May 2003.

Potts, Gwen. "Fanatism, Not Religion to Blame," dalam Edmonton Journal, 17 September 2010.

Preece, Sasha, \& David Mellor. "Learning Patterns in Social Skills Training Program: an Exploratory Study," dalam Child \& Adolescent Social Work Journal, 26, 2, April 2009. 
Prizmich, Heidi. "Mass Media Manipulation and Gender: The Message Advertisements Are Sending Young Girls.” Disertasi: Gonzaga University, 2015.

Pulliam, Susan, \& Frederick Rose. "Metropolitan Life to Take Lead Role With First Executive's New York Unit," dalam Wall Street Journal, 6 Apr 1991.

Rahim, Abd., et al., "The Retention of Sinrilik Values in Teaching Local Language and Literature of Makassar," dalam Journal of Language Teaching \& Research, Vol. 6 Issue 5, 2015.

Ritzer, George. Modern Sociological Theory. New York: The McGraw-Hill Companies, Inc, 1996), h. 235.

Roberts, Paul. "Instant Gratification," dalam American Scholar, Autumn 2014, Vol. 83, Issue 4.

S. Gavrilets. "Philosophical Transactions of the Royal Society of London," dalam Biological Sciences, Desember 2015, Vol. 370.

S. Tsirogianni, dan Sammut G. "Transitivity Analysis: a Framework for the Study of Social Values in the Context of Points of View," dalam the British Journal of Social Psychology, September, Vol. 53 (3), 2015.

Schutte, Nico, dan Nicolene Barkhuizen. "Electronic Journal of Knowledge Management," Agustus 2015, Vol. 13, Issue 2.

Schwarz, Adam. A Nation in Waiting: Indonesia Search for Stability. Washing: Allen dan Unwin, 1999.

Shiner, Roger A.. "Theorizing Criminal Law Reform," dalam Criminal Law and Philosophy, 3.2, (Jun 2009).

Shusterman, Richard. "Transactional Experiential Inquiry: From Pragmatism to Somaesthetics," dalam Contemporary Pragmatism, 2015, Vol. 12 Issue 1.

Slinger, Michael J. "Historical Development of the Librarian/Research Partnership in American Law Schools," dalam Journal of Law and Education, 39.3, Juli 2010.

Socci, Nataly. "Turkish Neigboughood Policy and EU Membership: Squering the Circle of Turkish Foreign Policy," dalam International Journal, 67.1 (Winter 2011/2012).

Song, Lijun. "Social Capital and Psychological Distress," dalam Journal of Health and Social Behavior, 52.4, Desember 2011.

Sulaiman al-Asyqar, Umar. al-Rasûl wa al-Risâlah. Amman: Dâr al-Nafa'is, 2002.

Syukur, Abdul. "Islam, Etnitas, dan Politik Identitas," dalam MIQOT: Jurnal Ilmu-ilmu Keislaman, Vol. XXXV, No. 2 Juli-Desember 2011.

Ufen, Andreas, \& Bunte Marco. Democratization in Post-Suharto Indonesia. London: Routledge, 2009.

W. More, Harry. "Teams-Groups-Task Forces in Law Enforcement: The Wave of the Future," Springfield: Charles C. Thomas, 2012.

Walker, Jason. "The Rule of Law as an Emergent Order: How Stare Decisis Generates the Rule of Law from the Ground Up." Disertasi: The University of Wisconsin, 2012. 
MIQOT Vol. XLI No. 2 Juli-Desember 2017

Winter, Elke. "Rethinking Multiculturalism After its "Retreat": Lessons From Canada," dalam American Behavioral Scientist, May 2015, Vol. 59, Issue 6.

Wood, Andy. "The Deep Roots of Albion's Fatal Tree: The Tudor State and the Monopoly of Violence," dalam History, Juli 2014, Vol. 99, Issue 336.

W ood, L isa. "T argetting E thnic T rade: M inorities by L isa W ood: M inority F rancisees A re U seful Role M odels in A ttracting $O$ ther Ethnic $G$ roups to Set $U p$ in Business-and $H$ ave the Experience of D oing So T hemselves," dalam Financial T imes. L ondon: 26 June 2001.

W ortham, Stanton \& C atherine R hodes. "Life as a C hord: H eterogeneous R esources in the Social Identification of O ne M igrant G irl," dalam A pplied Linguistics, D esember 2013, V ol. 34, I ssue 5.

W ortham, Stanton dan C atherine R hodes. "Life as a C hord: $\mathrm{H}$ eterogeneous R esources in the Social Identification of O ne M igrant G irl." dalam A pplied Linguistics, D esember 2013, V ol. 34 Issue 5.

"T hailand/A SEA N : First M eeting of A SE A N Political-Security C ommunity C ouncil A sia N ews M onitor." Bangkok, 14 A pril 2009. 